\title{
Reconstruction of eolian bed forms and paleocurrents from cross-bedded strata at Victoria Crater, Meridiani Planum, Mars
}

\author{
A. G. Hayes, ${ }^{1}$ J. P. Grotzinger, ${ }^{1}$ L. A. Edgar, ${ }^{1}$ S. W. Squyres,${ }^{2}$ W. A. Watters, ${ }^{2}$ \\ and J. Sohl-Dickstein ${ }^{3}$
}

Received 1 July 2010; revised 17 December 2010; accepted 31 January 2011; published 19 April 2011.

[1] Outcrop exposures imaged by the Opportunity rover at Victoria Crater, a $750 \mathrm{~m}$ diameter crater in Meridiani Planum, are used to delineate sedimentary structures and further develop a dune-interdune depositional model for the region. The stratigraphy at Victoria Crater, observed during Opportunity's partial traverse of its rim, includes the best examples of meter-scale eolian cross bedding observed on Mars to date. The Cape St. Mary promontory, located at the southern end of the rim traverse, is characterized by meter-scale sets of trough cross bedding, suggesting northward migrating sinuous-crested bed forms. Cape St. Vincent, which is located at the opposite end of the traverse, shows tabular-planar stratification indicative of climbing bed forms with meter- to decameterscale dune heights migrating southward. Promontories located between Cape St. Mary and Cape St. Vincent contain superposed stratigraphic units with northward and southward dipping beds separated by outcrop-scale bounding surfaces. These bounding surfaces are interpreted to be either reactivation and/or superposition surfaces in a complex erg sea. Any depositional model used to explain the bedding must conform to reversing northward and southward paleomigration directions and include multiple scales of bed forms. In addition to stratified outcrop, a bright diagenetic band is observed to overprint bedding and to lie on an equipotential parallel to the preimpact surface. Meter-scale cross bedding at Victoria Crater is similar to terrestrial eolian deposits and is interpreted as a dry dune field, comparable to Jurassic age eolian deposits in the western United States.

Citation: Hayes, A. G., J. P. Grotzinger, L. A. Edgar, S. W. Squyres, W. A. Watters, and J. Sohl-Dickstein (2011), Reconstruction of eolian bed forms and paleocurrents from cross-bedded strata at Victoria Crater, Meridiani Planum, Mars, J. Geophys. Res., 116, E00F21, doi:10.1029/2010JE003688.

\section{Introduction}

[2] Stratified sedimentary rocks observed in the crater walls of Meridiani Planum chronicle the paleoenvironments of Terra Meridiani and provide glimpses into the broader history of early Mars. The geometry, scale, and distribution of sedimentary structures on Mars have proven to be strikingly similar to deposits found on Earth, allowing the methods and principals of terrestrial-based sedimentology to be utilized on Martian analogs [Grotzinger et al., 2005]. The high-resolution ground-based imaging and mobility provided by the Mars Exploration Rovers (MER) have, for the first time, allowed geological analysis of nonterrestrial outcrops to be performed at a level of detail comparable to field studies on Earth. The quality and variety of data being

\footnotetext{
${ }^{1}$ Division of Geological and Planetary Sciences, California Institute of Technology, Pasadena, California, USA.

${ }^{2}$ Astronomy Department, Cornell University, Ithaca, New York, USA.

${ }^{3}$ Biophysics Group, University of California, Berkeley, California, USA.

Copyright 2011 by the American Geophysical Union. 0148-0227/11/2010JE003688
}

returned from Mars by the MER spacecraft have begun to bridge the gap between the terrestrial and planetary geological communities.

[3] Since landing in January 2004, the Opportunity rover has observed outcrop exposures within the walls of Eagle, Endurance, Erebus, and Victoria Craters. Each outcrop has provided information regarding the geologic history of the region, adding to the development of an eolian dune-interdune depositional model [Squyres et al., 2004b; Grotzinger et al., 2005, 2006; Metz et al., 2009; Squyres et al., 2009]. Eagle crater, in which Opportunity landed, contains 30-50 $\mathrm{cm}$ thick exposures of sulfate-rich outcrop which subtend half the crater's circumference [Squyres et al., 2004a]. Cross-bedded stratigraphy exposed in Eagle Crater suggest both subaerial and subaqeous origins [Squyres et al., 2004b; Grotzinger et al., 2005]. Burns Cliff, an outcrop with $7 \mathrm{~m}$ of exposed stratigraphy in Endurance Crater, contains evidence for a complex history of varying depositional processes and subsequent diagenetic alteration [Grotzinger et al., 2005; McLennan et al., 2005]. The base of Burns Cliff is composed of cross-bedded sandstone, indicative of an ancient eolian dune field, which progresses vertically into eolian 


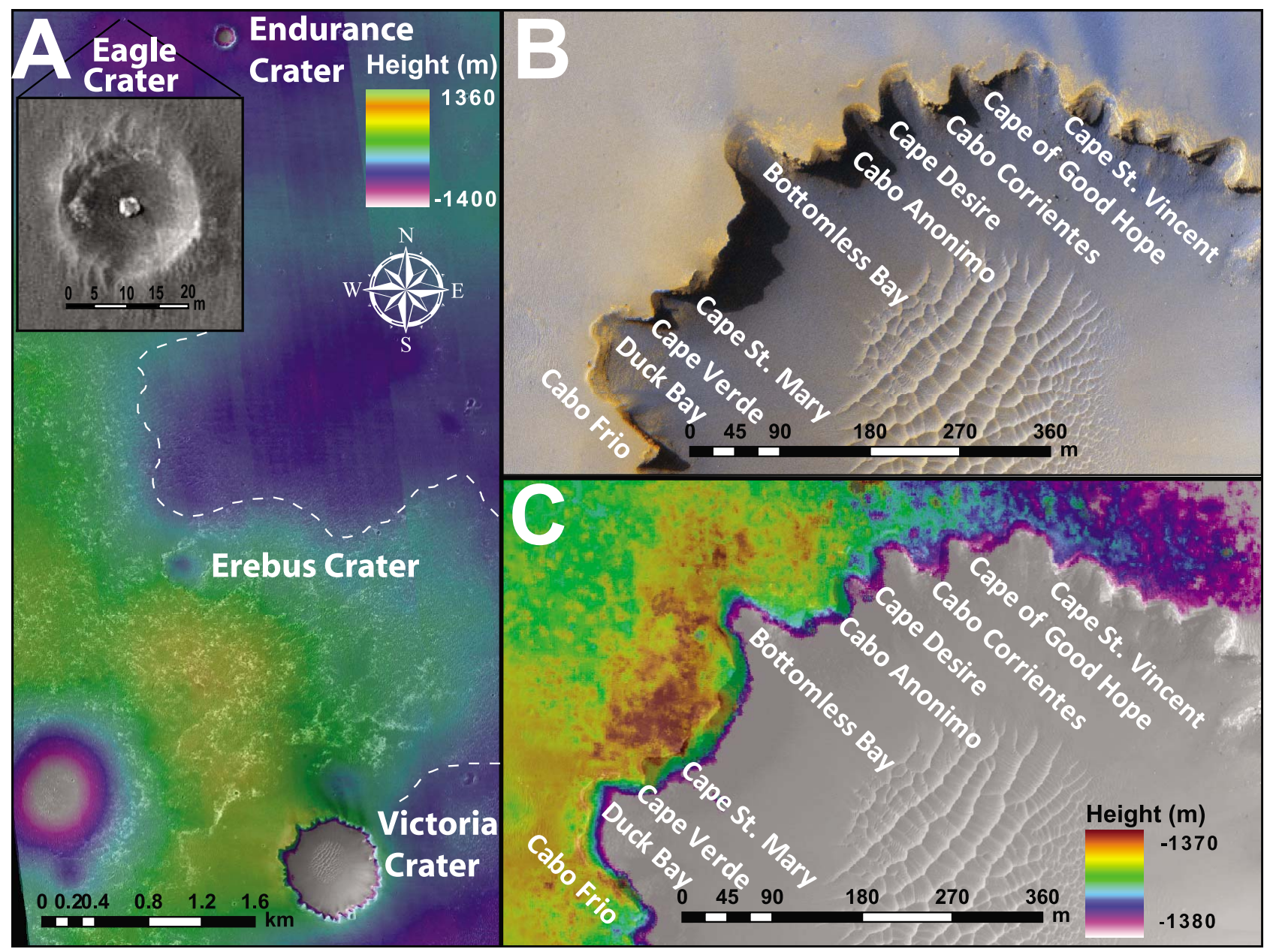

Figure 1. Equidistant cylindrical projection of the Opportunity landing site and traverse area using data from the High Resolution Imaging Science Experiment (HiRISE). Images are subframes of HiRISE image PSP_001414_1780 and PSP_009141_1780. Opportunity landed in Eagle Crater (Figure 1a inset) and followed a traverse path which included Endurance and Erebus craters prior to arriving at Victoria Crater in late September 2006. (a) Digital elevation model (DEM) of Opportunity's traverse path up to and including Victoria Crater. Prior to generating the DEM, HiRISE images were geo-referenced using the position of the lander in Eagle Crater and tied down vertically using Mars Orbital Laser Altimetry (MOLA) data. Victoria strata lie $\sim 20 \mathrm{~m}$ below the planes surrounding Eagle and Endurance Craters and have similar elevation to parts of Erebus Crater. The dashed line outlines exposures of light-toned sulfate-rich outcrop. (b) Portions of Victoria Crater investigated during the rim traverse which lasted 341 Martian sols prior to crater ingress at Duck Bay in September 2007. (c) DEM of investigated promontories. The plains immediately surrounding Victoria vary in elevation from $-1370 \mathrm{~m}$ at Cape St. Mary to $-1377 \mathrm{~m}$ at Cape St. Vincent. For reference, the rim of Erebus crater varies in elevation between $-1378 \mathrm{~m}$ and $-1374 \mathrm{~m}$.

sand sheet facies and, at the top of the section, into the remnants of an interdune playa environment [Grotzinger et al., 2005]. Bedrock exposures located in Erebus crater provided additional evidence for subaqueous deposition in the form of shrinkage cracks and rip-up clasts [Grotzinger et al., 2006; Metz et al., 2009]. As opposed to Burns Cliff, which was interpreted as a wetting upward sequence, facies at Erebus Crater show a drying upward sequence and have been interpreted to represent the completion of a full climatic cycle [Metz et al., 2009]. Alternative depositional models for these deposits have been proposed by McCollom and Hynek [2005], who suggests strata may represent a volcanic base surge deposit, and Knauth et al. [2005], who suggest a impact-induced based surge interpretation.

[4] Opportunity arrived at Victoria Crater (Figure 1) in late September 2006 and spent 341 Martian sols (952 to 1293) traversing the rim prior to entering the crater at Duck Bay (Figure 1b) on sol 1293 in September 2007 [Squyres et al., 2009]. The rim traverse, which covered approximately one fourth of the crater's circumference, was spent searching for a safe ingress path and imaging outcrops exposed by several promontories using the rover's Panoramic Cameras (Pancam). The rover egressed from the crater in late August 2008 on sol 1634. During its traverse, Opportunity obtained images of multiple outcrop exposures with up to $12 \mathrm{~m}$ of 
vertical thickness and $25 \mathrm{~m}$ of lateral extent. Bedding at Victoria Crater lies stratigraphically above previously investigated outcrop and consists entirely of cross-bedded sandstone. As discussed in the following, the sedimentary bed forms exposed at all of these outcrops are consistent with the remains of an ancient aeolian dune field migrating with predominantly northward and southward dominant paleowinds.

\section{Regional Setting}

[5] Meridiani Planum is located in the westernmost portion of Terra Meridiani, an albedo dark equatorial region $\left(13^{\circ} \mathrm{S}-7^{\circ} \mathrm{N}\right)$ of Mars stretching east-west $\left(10^{\circ}-\mathrm{E} 10^{\circ} \mathrm{W}\right)$ centered near the prime meridian. The area was chosen for Opportunity's landing site because of its relatively flat rockfree terrain and a $15-20 \%$ areal abundance of rare gray crystalline hematite, a mineral suggesting subaqueous formation [Squyres et al., 2004a; Christensen et al., 2000; Golombek et al., 2003]. Terra Meridiani consists of several light-toned outcrops which lie disconformably on top of a heavily cratered and dissected Noachian age basal unit [Edgett, 2005; Arvidson et al., 2003]. The light-toned layered outcrops are lithified sedimentary rock and known as "etched" terrain in northern Terra Meridiani [Presley et al., 1987], where they are heavily eroded, and "smooth" terrain in central Terra Meridiani, where the outcrops are considered to represent the upper surface of the "etched" terrain [Edgett and Parker, 1997]. Greater than $800 \mathrm{~m}$ of exposed stratigraphy has been reported in the light-toned layered terrain. To date, the Mars Exploration Rovers have investigated approximately $20 \mathrm{~m}$ of this section.

[6] The area surrounding the Opportunity landing site at Eagle Crater consists of uniformly flat plain with typical slopes of less than $1^{\circ}$ and a maximum of $20 \mathrm{~m}$ of topographic variation between Eagle and Victoria (Figure 1a). Exposures of light-toned sulfate-rich outcrop lie 15-20 m above sediment filled depressions separated by a sinuous north-south trending boundary (Figure 1a). Victoria Crater is located $6 \mathrm{~km}$ south of Eagle and Endurance Craters and $2.5 \mathrm{~km}$ south-southeast of Erebus Crater. The plains surrounding Eagle and Endurance, which lie $800 \mathrm{~m}$ apart in an east-west direction, are 13-20 m below the tops of investigated promontories at Victoria. Erebus Crater lies 5-10 m below the highest point of Victoria's rim and is located on the border between the light-toned exposures and sediment filled depressions. The southwest border of Erebus Crater, which contains the outcrops explored by Opportunity (Olympia, Payson, and Yavapai), is $\sim 5 \mathrm{~m}$ above the northeast border. Elevations of explored promontories at Victoria Crater vary by $\sim 7 \mathrm{~m}$ around the investigated sections of the crater rim (Figure 1c).

[7] Victoria itself is a $\sim 75 \mathrm{~m}$ deep heavily degraded impact crater $\sim 750 \mathrm{~m}$ in diameter located at $\left(2.078^{\circ} \mathrm{S}\right.$, $\left.354.500^{\circ} \mathrm{E}\right)$. The serrated edges of Victoria were created predominantly by eolian processes with a lesser extent of mass wasting [Grant et al., 2008]. Prevailing winds have elongated the crater by $50 \mathrm{~m}$ in a west-northwest direction [Grant et al., 2008]. The star dunes at the floor of the crater are primarily composed of modern basaltic sediment while the walls of the crater show an enhancement in nanophase iron oxide, consistent with coatings or weathering rinds
(R. E. Arvidson, personal communication, 2009). The surrounding region consists of sulfates mixed with modern basaltic sediment [Christensen et al., 2004].

[8] The Burns Formation refers to the bedrock stratigraphy explored by Opportunity at Meridiani Planum that includes a range of sulfate-rich sedimentary rocks identified on the basis of distinct suites of stratification styles indicating largely eolian and, less commonly, fluvial processes [Grotzinger et al., 2005]. At Burns Cliff in Endurance Crater, the Burns Formation is divided into lower, middle, and upper units based on facies changes that suggest a wetting upward sequence of depositional environments [Grotzinger et al., 2005]. Erebus crater exposed an additional 5-10 m of stratigraphy that suggested a set of facies indicative of a drying upward sequence [Metz et al., 2009]. Victoria Crater adds another $12 \mathrm{~m}$ of stratigraphy to the Burns Formation (section 4). However, this value is a maximum because of partial overlap with stratigraphy at Erebus.

\section{Methodology}

\subsection{Data Collection}

[9] Mosaics of outcrop exposures observed at each promontory were acquired systematically from the rims of neighboring promontories during Opporunity's traverse of Victoria Crater. Images were primarily obtained using the Panoramic Camera's red $(753 \mathrm{~nm})$, green $(535 \mathrm{~nm})$, and blue $(433 \mathrm{~nm}) 20 \mathrm{~nm}$ bandpass filters. Pancam obtains a $16^{\circ}$ field of view imaged at a pixels scale of $27 \mathrm{mrad}$. Higher resolutions were obtained by using superresolution techniques which involve acquiring multiple images while slightly moving the mast assembly between exposures [Bell et al., 2006]. Superresolution sequences were used to enhance the detail of observed bedding at Cape St. Vincent, Cape St. Mary, and Cape Verde (Figures 4, 5, 8, 9, and 10). Threedimensional locations for image pixels were obtained through coregistration of stereo image pairs, utilizing the $30 \mathrm{~cm}$ baseline between Pancam eyes [Bell et al., 2003]. Higher relative accuracy was obtained by extending the baseline to meter scale by moving the rover in between subsequent observations, allowing reliable stereo information to be generated for targets with ranges in excess of $100 \mathrm{~m}$ [Di et al., 2008]. With the exception of the north face of Cape Verde, long-baseline stereo image pairs were acquired during observations of each promontory at Victoria Crater. Unless otherwise noted, stereo data were processed using the red filter, which provides optimal contrast. While the blue filter has an inherently higher resolution, as Pancam is near diffraction limited, the reduced contrast ratio and increased frequency of image artifacts reduced the quality of the resulting long-baseline stereo models in this channel.

[10] Most promontories are imaged at distances between $30 \mathrm{~m}$ and $100 \mathrm{~m}$. At this range, pixel scale is $1-3 \mathrm{~cm}$, placing the details of many bedding contacts below image resolution. An exception is Cape Verde, where the rover was able to obtain images from a distance of $6 \mathrm{~m}$, or a scale of approximately $2 \mathrm{~mm} /$ pixel. Promontories were georeferenced using a digital elevation map (DEM) derived from orbital imagery to allow correlation between outcrops. The DEM was created using images from the HiRISE instrument on the Mars Reconnaissance Orbiter, which were 


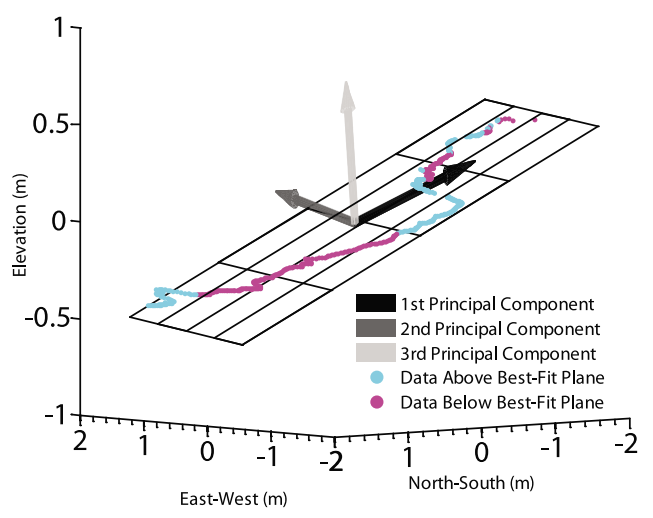

Figure 2. Principal component analysis (PCA) of threedimensional pixel locations for the lower bounding surface of the east face of Cape Desire. The first two principal components define the best fit plane. In this example, $90 \%$ of the variance is explained along the first component, $10 \%$ along the second, and $<0.1 \%$ is explained along the third. Data are plotted with a $2 \mathrm{X}$ vertical exaggeration.

geo-referenced spatially using the position of Opportunity's lander in Eagle Crater and tied down vertically using data from the Mars Orbital Laser Altimeter (Figure 1). The modern surface at the top of each promontory dips in an eastward direction and results in the $\sim 7 \mathrm{~m}$ difference between the top of Cape Verde and the top of Cape St. Vincent, located at the furthest points of the rim traverse.

\subsection{Analytical Methods}

[11] In order to obtain the accuracy required to calculate three-dimensional bedding orientations, stereo data were generated using all possible image pairs of a given outcrop in long-baseline geometry. The resulting stereo maps were then coreferenced and averaged to reduce error. Baselines varied from 2 to $5 \mathrm{~m}$ between observations. Individual bedding orientations are calculated using principal component analysis [Dunteman, 1989], with the best fit plane defined by the first two principal components in a Cartesian coordinate system (Figure 2). Measured strikes and dips are filtered such that observations with less than one percent of their variance explained by the second principal component are removed. Additional constraints are imposed on the importance of the third principal component to ensure each data cloud is adequately represented by a two-dimensional surface. Dips that are oriented within $5^{\circ}$ of the local outcrop slope or camera bore sight are removed from the data set. Error estimates on derived strike and dips are found using the bootstrap Monte Carlo technique described in Appendix A of Watters et al. [2011]. Unless otherwise stated, all errors reported in this manuscript represent one standard deviation
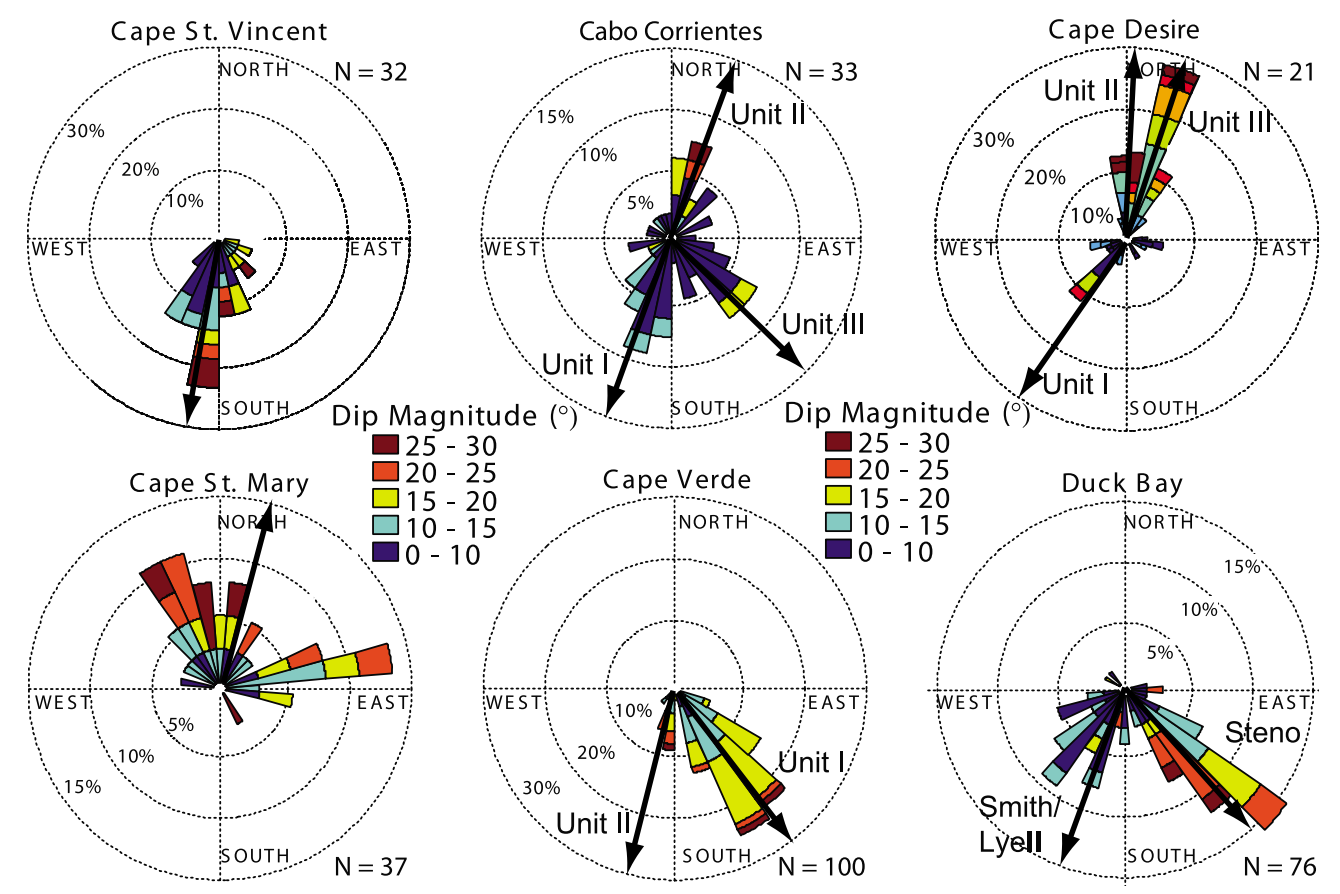

Figure 3. Rose histograms for foreset orientations measured at each promontory. Azimuths are measured clockwise positive from north and defined as the direction of steepest decent in the plane of the measured bedding. Dips represent the angle of steepest decent for the plane defined by the first and second principal components of selected Cartesian points. Colors correspond to dip magnitude, and the length of each color patch represents the relative significance of a given dip within an azimuth bin. Cape St. Vincent and Capt St. Mary have single distributions, while Cabo Corrientes, Cape Desire, and Cape Verde exhibit multiple distributions that correlate to difference stratigraphic units separated by outcropscale bounding surfaces. The number of points used to create each histogram is shown in the upper right of each diagram in the top row and lower left of each diagram in the bottom row. Median dip azimuths are depicted using black arrows for each bedding unit. 


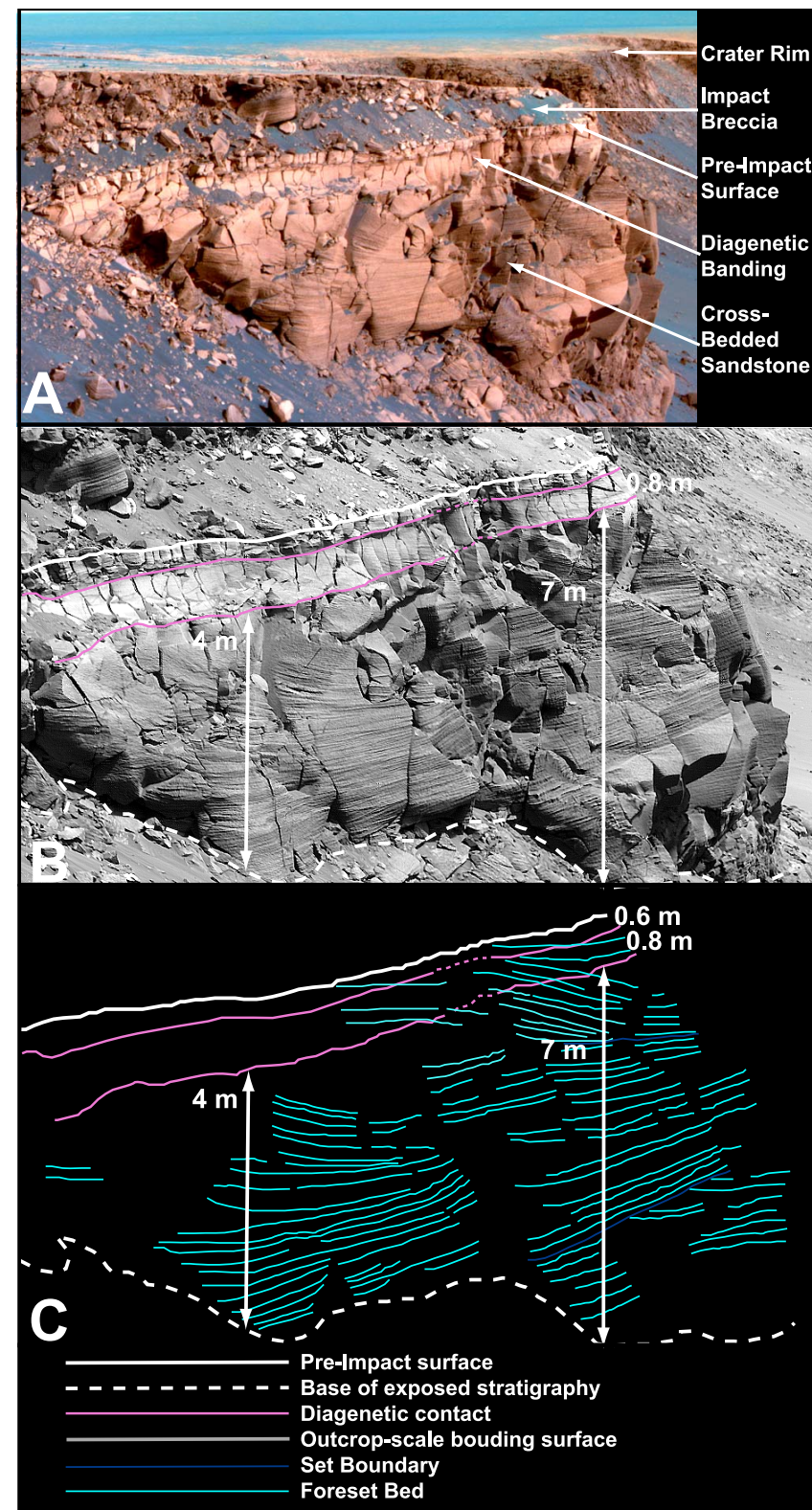

Figure 4. West face of Cape St. Vincent. (a)False color image acquired on sol 1167 (6 May 2007), sequence P2419, using Pancam's $753 \mathrm{~nm}, 535 \mathrm{~nm}$, and $432 \mathrm{~nm}$ filters. (b) Superresolution image of Cape St. Vincent generated from sequence P2417 acquired on sol 1167 using Pancam's $480 \mathrm{~nm}$ filter. (c) Layer tracing of Figure $4 \mathrm{~b}$. Line widths and colors are defined at the bottom. Layering consists of meter-scale sets of low- to high-angle climbing tabular-planar cross stratification consistent with meter- to decameter-scale dune heights migrating parallel to the outcrop face in a southward direction.

or the $68 \%$ confidence interval $(\mathrm{CI})$. The stereo maps used for each strike and dip calculation were visually inspected to verify that data points represented actual topography on the outcrop as opposed to fictitious elevations resulting from misregistration or shadowing effects. Rose diagrams for the foreset dip magnitudes and azimuths measured at each promontory are shown in Figure 3. Azimuths are measured clockwise positive from north $\left(0^{\circ}\right)$ and defined as the direction of steepest decent in the plane of the measured bedding, perpendicular to the strike line of the beds.

\section{Stratigraphy}

[12] Meter-scale cross stratification is present in all promontories; most notably Cape St. Vincent and Cape St. Mary, where grouped bed sets are observed (Figures 1, 4, and 8). Elsewhere bedding is massive, thinly bedded, or observed as finely laminated (centimeter scale or smaller) low- to high-angle cross stratification lacking clearly observable bed set boundaries. A summary of observed stratigraphy is provided in Table 1. Detailed facies descriptions, based on Pancam remote sensing, are provided below as observed at Cape St. Vincent, Cabo Corrientes, Cape Desire, Cape St. Mary, Cape Verde, and Duck Bay. Cabo Anonimo, Bottomless Bay, and Cabo Frio are listed in Table 1, but the bedding exposed at these promontories was either too brecciated or too distant to accurately measure and calculate consistent foreset orientations. The Duck Bay ingress section, which has been developed as a reference section for Victoria Crater, is further described by Edgar et al. [2011]. The observed promontories are dominated by eolian facies (section 5), so eolian terminology will be used to describe their stratigraphy.

\subsection{Cape St. Vincent}

[13] Cape St. Vincent (Figure 4a) is located at the end of the rim traverse, near the northernmost extent of Victoria Crater. The southwest face contains an outcrop with $\sim 18 \mathrm{~m}$ of laterally exposed bedding. The outcrop has a southsoutheast trend $\left(\phi=249^{\circ}\right)$ and an average slope of $67^{\circ}$ that provides up to $8 \mathrm{~m}$ of vertically exposed bedding. Largescale sets of low- to high-angle cross stratification dominate the outcrop (Figure $4 \mathrm{~b}$ ). Foresets are concave upward and asymptotically lap down against the lower bounding surface of each set. Cross bed sets are $\sim 4 \mathrm{~m}$ thick, although they are laterally more extensive than the exposed outcrop. Foresets show a vertical increase in dip from $4^{\circ}$ to $25^{\circ}$ within each set. The median foreset dip azimuth is south-southwest $\left(190^{\circ} \pm 18^{\circ}\right)$. An absolute measure of the angle of bed form climb is difficult because the outcrop has a structural dip of $\sim 3^{\circ}$ to the north, likely generated by the impact event, but the geometry of observed set boundaries suggest values of $<1^{\circ}$. No erosional surfaces other than foresets and set boundaries are apparent in the outcrop.

[14] A $1.4 \mathrm{~m}$ thick light-toned band at the top of outcrop is superimposed on bedding and lies within $3^{\circ}$ of the horizontal in a plane approximately parallel to the preimpact surface. Because it crosscuts primary bedding, the light-toned band is interpreted to have a diagenetic origin (Figure 5). The top $0.6 \mathrm{~m}$ of the bright band appears fractured in place while the remaining $0.8 \mathrm{~m}$ is structurally similar to the remainder of the outcrop. The light-toned band locally dips away from the crater, consistent with an impact induced stratigraphic uplift, suggesting that the diagenetic event predates the impact but postdates the stratigraphy. Using observations from orbit and rover images of other promontories, the light-toned band can be traced around the entirety of the crater rim and appears to lie on an equipotential plane parallel to the modern erosional surface. 


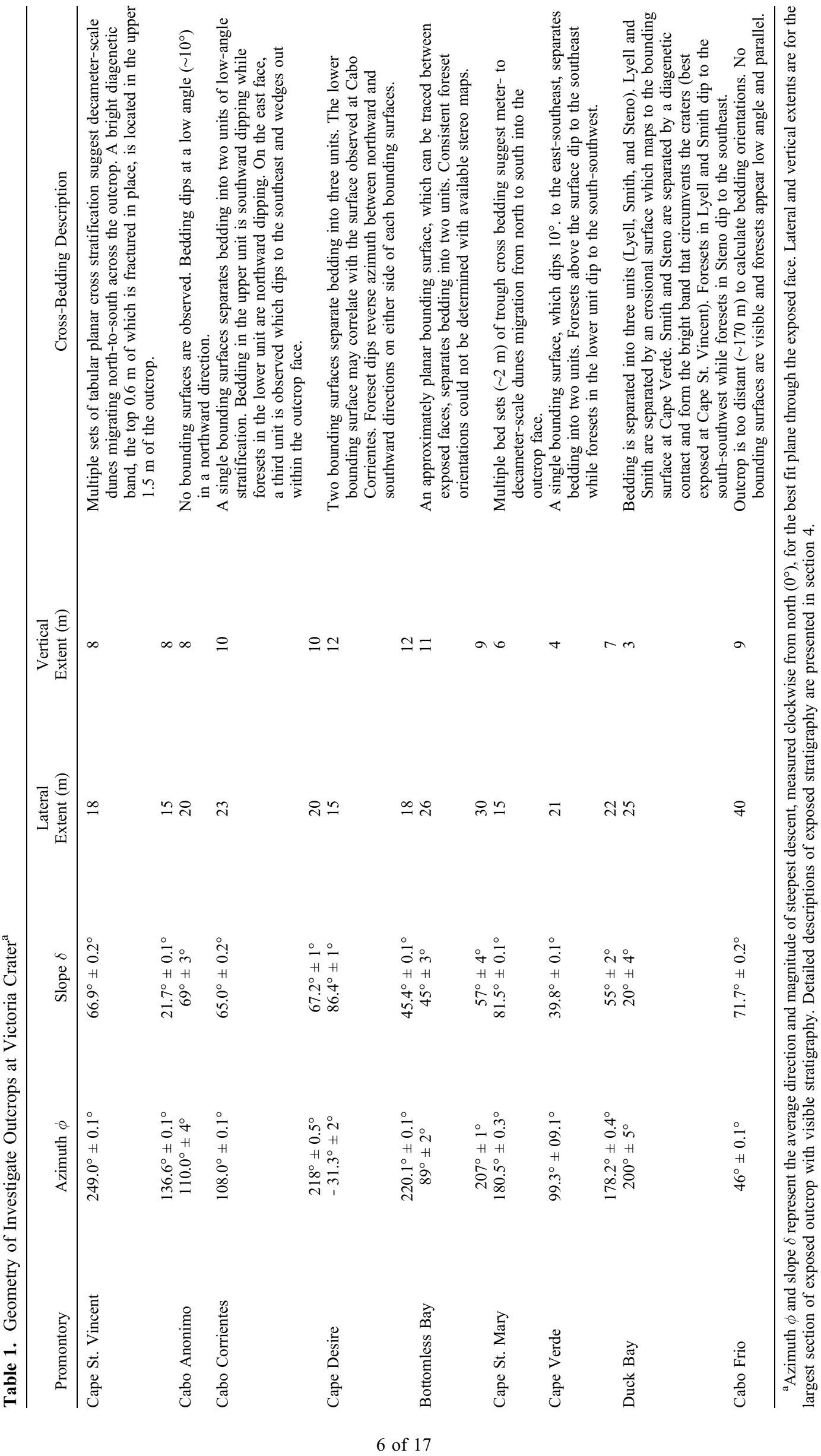




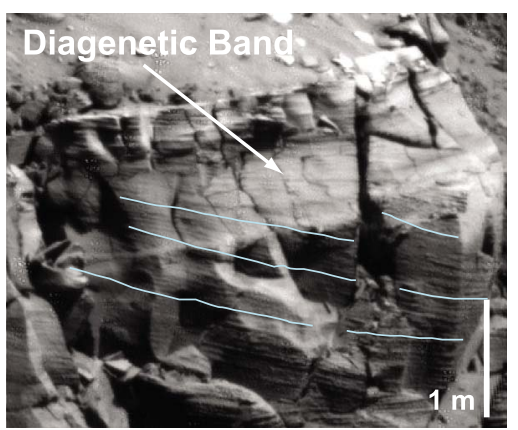

Figure 5. Subframe of Cape St. Vincent superresolution image (Figure $4 \mathrm{~b}$ ) showing that the light-toned band crosscuts primary bedding, indicating a diagenetic origin.

[15] The east face of Cape St. Vincent has an average slope of $23^{\circ}$ and trends toward the southwest $\left(\phi=137^{\circ}\right)$. Similar to the west face there is a maximum of $8 \mathrm{~m}$ of vertical outcrop exposure, although the bedding is covered with debris and is generally brecciated. Exposed bedding is mostly low angle, and dip azimuths are consistent with the exposures on the west face. Some high-angle cross bedding is found in the uppermost part of the south end of the outcrop. The stratification at Cape St. Vincent suggests lowangle climbing bed forms with meter to decameter-scale dune heights migrating parallel to the outcrop face (section 5). Bedding strikes and dips are consisted with a north-to-south transport direction, although an absolute measure of the paleocurrent direction is not possible without observing additional set boundaries and outcrop orientations.

\subsection{Cabo Corrientes}

[16] Outcrop exposures at Cabo Corrientes (Figure 6), which face to the south and east, are highly faceted and produces complex shadowing that hinders stereo processing, making it difficult to determine foreset geometry in some areas of the promontory (particularly near the crater rim). The south face $\left(\phi=218^{\circ}\right)$, which is approximately $20 \mathrm{~m}$ in length and has slopes of $50^{\circ}-80^{\circ}$, exposes up to $10 \mathrm{~m}$ of strata. The east face $\left(\phi=108^{\circ}\right)$ has an average outcrop slope of $65^{\circ}$. A bounding surface which runs the length of the outcrop, and can be traced on both faces, forms the basis for subdividing the south side of the promontory into two stratigraphic units. This bounding surface dips approximately northward with a magnitude of $6^{\circ} \pm 4^{\circ}$. Bedding in the unit above the surface is southward dipping with dip magnitudes that tend to decrease from $\sim 15^{\circ}$ near the crater rim to approximately planar $\left(\leq 5^{\circ}\right)$ near the edge of the promontory (Figure 3). The bedding in the unit below the bounding surface consists of low-angle cross stratification with dip magnitudes of $12^{\circ} \pm 6^{\circ}$ and a north-northeast azimuth. Bedding in the lower unit shows evidence for trough-shaped sets, consistent with an oblique orientation relative to flow [DeCelles et al., 1983]. Foresets on the east face, which is roughly parallel to the average bedding dip azimuth, are more planar than those exposed on the south face. The east face of Cabo Corrientes shows an additional unit of southeast dipping $\left(\sim 140^{\circ}\right)$ low-angle $\left(9^{\circ} \pm 5^{\circ}\right)$ stratification which pinches out east of the western limit of the outcrop. The upper unit at Cabo Corrientes is more resistant to weathering than the lower unit and forms a protruding topographic overhang along the bounding surface (Figure 6b). In addition, the upper unit has a higher albedo and contains a continuation of the diagenetic light-toned band observed at Cape St. Vincent. Interpretations regarding the origin of bounding surfaces observed at Cabo Corrientes and other promontories are presented in section 5 .

\subsection{Cape Desire}

[17] Cape Desire (Figure 7) is situated between Cabo Corrientes and Cabo Anonimo in the northwest section of Victoria Crater. The two faces of the promontory, which trend southwest-northeast $\left(\phi=220^{\circ}\right)$ and southeast-northwest $\left(\phi=-31^{\circ}\right)$, expose up to $12 \mathrm{~m}$ of strata which pinch out laterally to the northwest over a distance of $\sim 18 \mathrm{~m}$. Strata exposed at the base of the outcrop along the southwest face provide an oblique-to-dip viewing geometry. Exposed strata form three units separated by two bounding surfaces that can be traced around the promontory. All three units consist of low- to high-angle cross strata which are truncated at these bounding surfaces. The lower bounding surface dips at a low angle $\left(\sim 6^{\circ}\right)$ in an approximately northwestern direction, although these measurements are uncertain due to the lack of topographic relief on the outcrop face. The upper erosional surface has a low $\operatorname{dip}\left(<10^{\circ}\right)$ to the north-northeast, consistent with the bedding in the uppermost unit (Figure 7c).

[18] The lowermost unit (Figure 7a) dips to the northnortheast with a median dip magnitude of $22^{\circ} \pm 7^{\circ}$. Dip magnitudes increase lower in the section, with the highest dips observed near the southern base of the outcrop where northward dips as high as $60^{\circ}$ can be found (Figure 7). Dips of this magnitude require deposition beyond the angle of repose or, more likely, postdepositional rotation/deformation. At least two scenarios of postdepositional tilting can explain these observations; collapse of underlying strata or a syndepositonal impact event. While this observation may warrant further investigation, as dips of this magnitude have not been observed elsewhere in Victoria Crater, we do not further pursue it here.

[19] Although no meter-scale set boundaries are obvious in the bedding at Cape Desire, the foreset geometry in the east-west trending tip of the promontory are more concave and sigmoidal, consistent with an oblique orientation relative to the paleocurrent [Kocurek, 1991]. The middle unit (Figure $7 \mathrm{~b}$ ) is a wedge shaped package of low-angle foresets bounded by the two outcrop-scale bounding surfaces. The foresets are planar and dip at low angles, with a median magnitude of $6^{\circ} \pm 10^{\circ}$. The azimuths of these shallow beds are difficult to determine, but seem to have a southward direction (Figure 3). The uppermost unit (Figure 7c) consists of planar, low- to high-angle cross stratification dipping to the north-northeast with a magnitude of $16^{\circ} \pm 6^{\circ}$. The uppermost unit appears more resistant to weathering and contains thicker strata $(2-4 \mathrm{~cm})$ than the lower units $(<1-2 \mathrm{~cm})$. The maximum exposed thickness is $6 \mathrm{~m}$ for unit I and $3 \mathrm{~m}$ for units II and III (Figure 7). The dip azimuth of foresets in units II and III, coupled to the position of Cape Desire relative to nearby promontories, suggests that the lower bounding surface may correlate with the outcropscale bounding surface observed at Cabo Corrientes. 


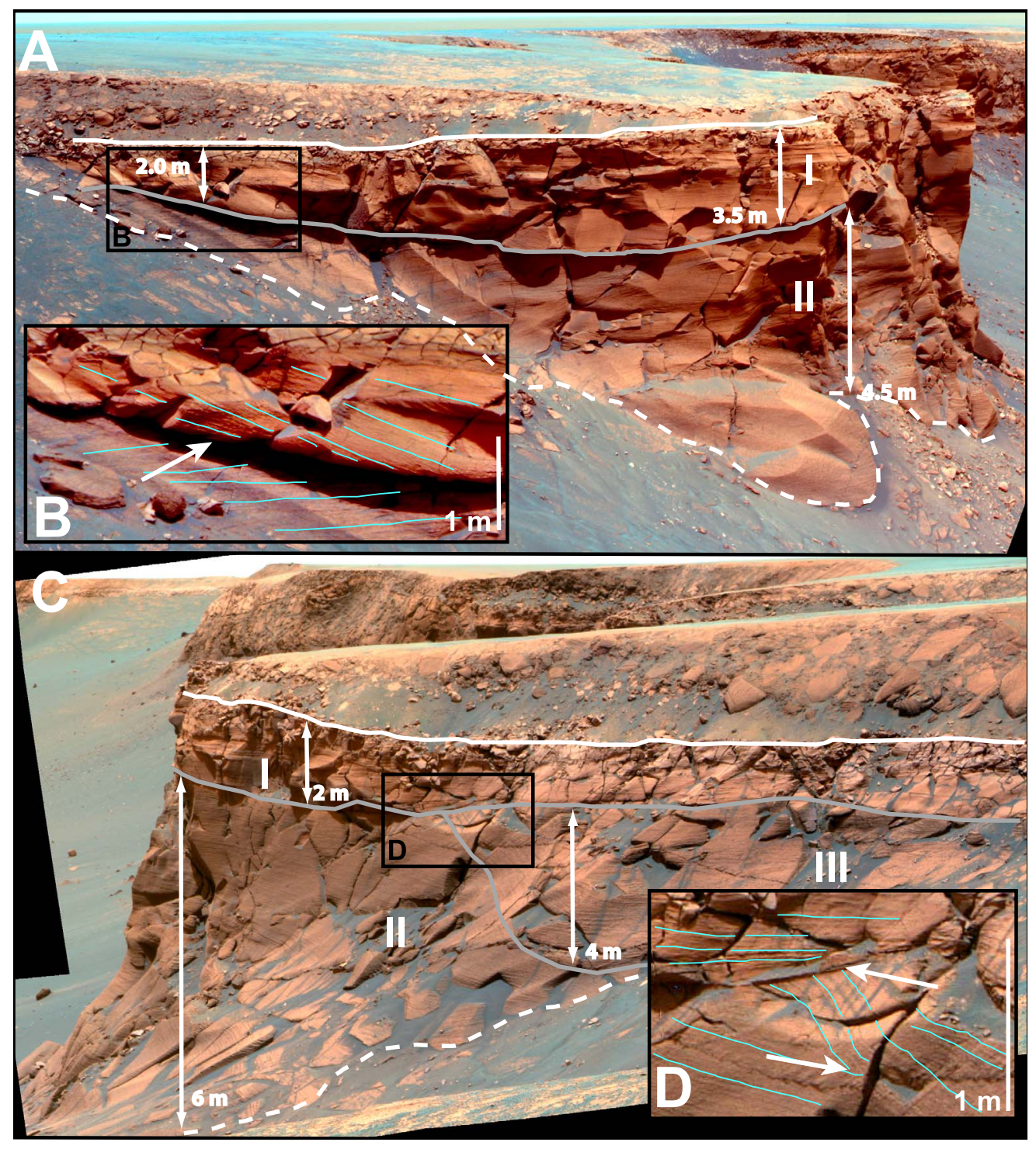

Figure 6. (a) False color image of the south face of Cabo Corrientes acquired on sol 1073 (20 January 2007), sequence P2360, using Pancam's $753 \mathrm{~nm}, 535 \mathrm{~nm}$, and $432 \mathrm{~nm}$ filters. An erosional bounding surface runs the length of the outcrop, separating the face into two primary stratigraphic units. The upper unit consists of southward $\left(\sim 110^{\circ}\right)$ dipping beds while the lower unit contains northward $\left(0^{\circ}-25^{\circ}\right)$ dipping beds. (b) Westernmost section of exposed truncation surface. The bounding surface can be followed around the promontory. (c) False color image of the east face of Cabo Corrientes acquired on sol 1108 (7 March 2007), sequence P2384, using Pancam's $753 \mathrm{~nm}, 535 \mathrm{~nm}$, and $432 \mathrm{~nm}$ filters. In addition to the two stratigraphic units exposed on the south face, an additional wedge-shaped unit of southeast dipping low-angle stratification is observed (unit III). (d) Intersection of all three exposed units on the east face, showing examples of two bounding surfaces. The bright diagenetic band can be seen at the top of the outcrop, just below the preimpact surface. Line colors are defined in the legend of Figure 3.

\subsection{Cape St. Mary}

[20] Cape St. Mary (Figure 8a) is a south facing outcrop with bedding exposed laterally over $15 \mathrm{~m}$, and dominated by a $6 \mathrm{~m}$ high exposure of meter-scale sets of trough cross bedding. Bed sets are approximately $2 \mathrm{~m}$ thick and at least 10 are discernable in the outcrop (Figure 8 b). This stratification is indicative of decameter-scale, sinuous-crested, eolian sand dunes migrating at high angles relative to the face of the outcrop [Kocurek, 1991]. Foresets define troughs that downlap asymptotically against the lower set boundary and indicate a transport direction that was nearly perpendicular to the exposed bedding [DeCelles et al., 1983]. Cape St. Mary is east-west trending $\left(\phi=180^{\circ}\right)$ with an outcrop slope of $81.5^{\circ}$ tilting toward the north. Cross-bed foresets have dips of $5^{\circ}-45^{\circ}$ with a median value of $15^{\circ}$. Dip azimuths show a bimodal spread of over $200^{\circ}$, reflecting the 


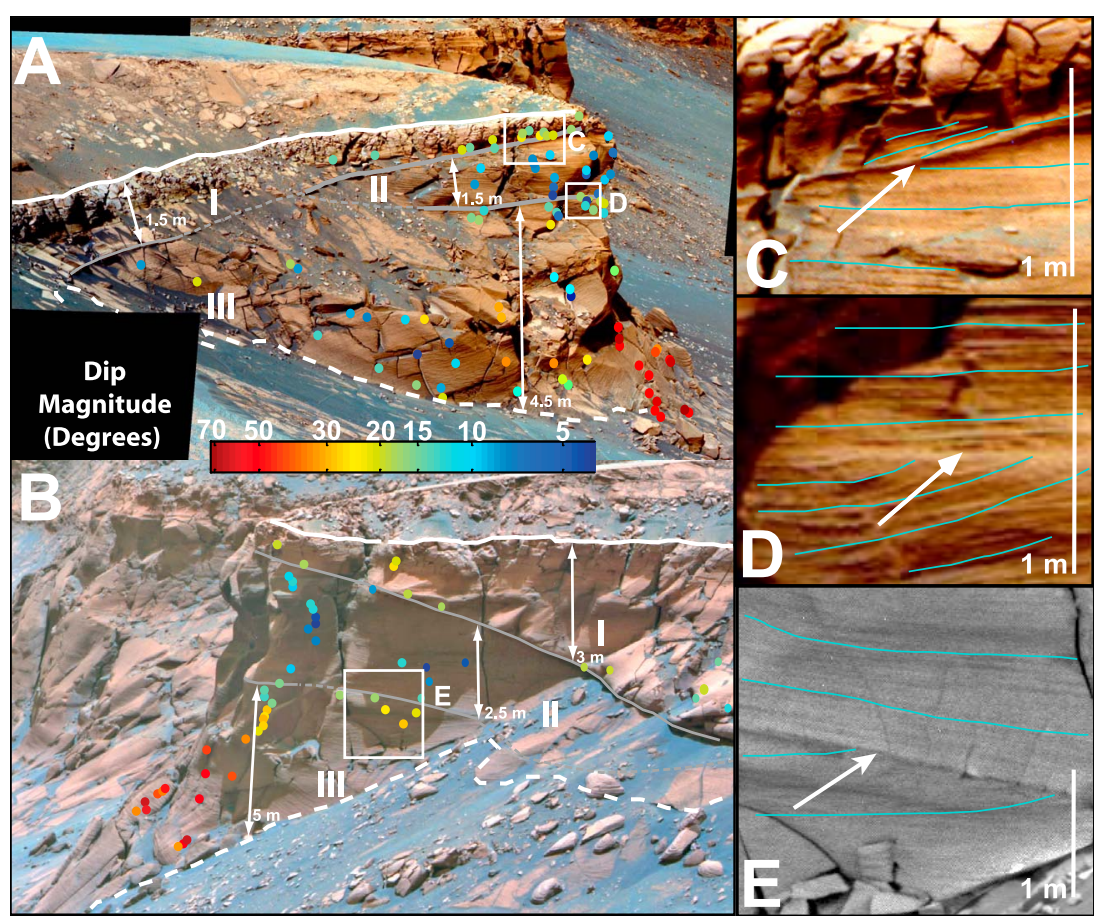

Figure 7. False color images of the (a) southwest and (b) southeast faces of Cape Desire acquired using Pancam's $753 \mathrm{~nm}, 535 \mathrm{~nm}$, and $432 \mathrm{~nm}$ filters. Dip magnitudes are depicted and observed to decrease with vertical position in the outcrop. The largest dips, found at the eastern base of the promontory, are in excess of $60^{\circ}$, suggesting postdepositional rotation during deformation. Exposed strata form three units which are separated by two bounding surfaces. Bedding in unit I is northward dipping with a magnitude of $\sim 10^{\circ}$. Unit II consists of low-angle $\left(<6^{\circ}\right)$ southward dipping cross stratification. The lowermost unit (III) is northward dipping with a median magnitude of $\sim 20^{\circ}$. The bounding surfaces can be traced around the promontory and are observed on both faces. The southwest facing exposure (Figure 7a) was imaged on sol 1060 (16 January 2007) during sequence P2350. The eastward facing outcrop image was acquired on Sol 1095 (21 February 2007) during sequence P2371. (c, d, and e) Examples of the bounding surfaces separating units I, II, and III. The bright diagenetic band is initially coincident with the upper bounding surface, but diverges to maintain thickness near the crater rim.

trough geometry, with a median of $20^{\circ} \pm 55^{\circ}$, consistent with a south-to-north transport direction. Bedding orientations were predominantly calculated in areas of the outcrop where layers could be traced around topographically varying terrain, optimizing the goodness of fit for strike and dip measurements. The diagenetic band observed at Cape St. Vincent appears near the top of the outcrop. Small decimeter-scale features observed the layering (Figure 9) are indicative of three-dimensional bed forms formed in the complex wind patterns existing in the troughs of migrating sand dunes. On Earth, bed forms of this size are rare and would require a large sediment supply to support the observed high angles on climb. On Mars, however, such features appear to be more common, such as the large-scale wind ripples discussed by Ewing et al. [2010].

\subsection{Cape Verde}

[21] Cape Verde (Figure 10) is a $22 \mathrm{~m}$ long promontory that bounds the northern edge of Duck Bay, where Opportunity entered the Victoria in September 2007. Cape Verde's south face, which is an east-west trending outcrop with $7 \mathrm{~m}$ of vertically exposed strata, was imaged at millimeter-scale resolution from a stand-off distance of $6 \mathrm{~m}$. Cape Verde exposes two units, separated by a bounding surface near the base of the cliff (Figures 10a and 10b). The surface truncates underlying bedding and is concordant with overlying bedding. The overlying strata dip $10^{\circ}-13^{\circ}$ with an eastsoutheast azimuth $\left(110^{\circ}-130^{\circ}\right)$. Less than $0.5 \mathrm{~m}$ of the lower unit is exposed, making interpretation of the stratification difficult. In places where the lower unit shows topographic variation relative to the outcrop face, dips of $10^{\circ}-20^{\circ}$ are found with azimuths between $170^{\circ}$ and $200^{\circ}$ (south).

[22] The upper unit consists of low-to-high-angle cross stratification with dips to the southeast $\left(140^{\circ}\right)$ that steepen upward in the outcrop. Dip magnitudes range from low angle $\left(6^{\circ}-15^{\circ}\right)$ near the base of the cliff to high angle $\left(18^{\circ}\right.$ $28^{\circ}$ ) in the uppermost sections. Strata near the truncation surface are have $3-5 \mathrm{~cm}$ thick beds and show lenticular geometry near the eastern edge of the outcrop, where the trend of the exposed face is closer to east-southeast $(\phi=$ $\left.190^{\circ}-200^{\circ}\right)$. Stratification in the upper part of the outcrop is thinner ( $2 \mathrm{~cm}$ or less) and shows evidence for centimeter to decimeter-scale wind ripple stratification superimposed on primary bedding. Super resolution imagery of Cape Verde also allows for the identification of distinct diagenetic features, including truncated and crosscutting fracture fills (Figure 10c), preferentially eroded bedding (creating an erosional ridge in the uppermost sections of the outcrop), 


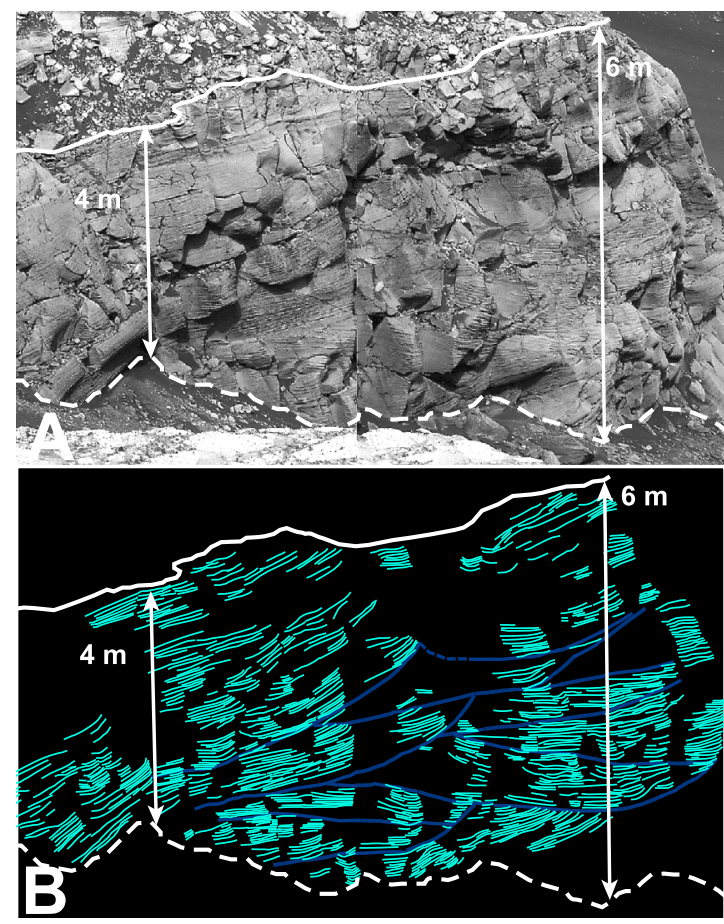

Figure 8. South face of Cape St. Mary. (a) Superresolution image of Cape St. Mary generated from sequence P2441 on sol 1212 (6 June 2007) using Pancam's $480 \mathrm{~nm}$ filter. (b) Layer tracing. Exposed outcrop consists of meter-scale sets of trough cross bedding that is indicative of decameterscale, sinuous crested, eolian sand dunes migrating in a direction approximately perpendicular to the face of the outcrop. Dip azimuths (Figure 3) suggest a northward flowing paleocurrent. The mosaic seam in the center of the image is a result of the complex outcrop geometry and does not hinder analysis or interpretation.

and ribbed weathering superimposed on cross strata, which is interpreted as differential cementation.

[23] The north face of Cape Verde is a north-south trending $\left(\phi=99.3^{\circ}\right)$ outcrop with $\sim 3 \mathrm{~m}$ of exposed bedrock and $\sim 2 \mathrm{~m}$ of fractured bedrock below impact generated breccias. Strata exhibit low-angle cross stratification similar to the lowermost part of the upper unit on the south face. Strike and dip measurements were not possible on the north face of Cape Verde as long-baseline stereo observations were not obtained and the rover's stand-off distance was too great for stereo derived from the nominal Pancam left-right separation.

\subsection{Duck Bay (Ingress Reference Section)}

[24] The stratigraphy at Duck Bay, where Opportunity entered Victoria Crater, is discussed in detail by Edgar et al. [2011] and only the general stratigraphy and its correlation to the promontories are discussed here. The ingress Reference Section (Figure 11) represents approximately $2.1 \mathrm{~m}$ of strata exposed on slopes varying from $10^{\circ}-30^{\circ}$ (at the location of Figure 11). Duck Bay is referred to as a "reference section" because it forms the basis for comparison to all other sections at Victoria Crater due to the fact that its was studied in detail by Opportunity, including in situ instrument deployment device (IDD) analysis. Three infor- mal units are recognized in the section, which in ascending stratigraphic order are Lyell, Smith, and Steno. Gilbert refers to the area below Lyell where stratigraphy is not exposed. There is no erosional or diagenetic contact which distinguishes Gilbert from Lyell. The contact between Lyell and Smith is gradational and represents a textural difference attributed to diagenetic alteration. The Lyell-Smith contact dips $2-3^{\circ}$ toward the crater rim, consistent with the impact induced uplift observed at Cape St. Vincent and other promontories around Victoria. In contrast, the contact between Smith and Steno is erosional, dipping $10^{\circ}-13^{\circ}$ to the east-southeast $\left(\phi=120^{\circ}\right)$. The Lyell unit varies in exposed thickness but is typically $1-2 \mathrm{~m}$ in true thickness (4-6 m along slope) and composed of low-angle meterscale cross bedding. Bedding orientations were determined near the Lyell-Smith contact and found to dip at low angles $\left(8^{\circ} \pm 5^{\circ}\right)$ to the south-southwest $\left(\phi \sim 200^{\circ}\right)$. At the location depicted in Figure 11 the Smith unit is one meter thick and appears massive, but shows faint palimpsest stratification that can be traced across the Lyell-Smith contact suggesting a diagenetic origin. The Steno unit is $0.6 \mathrm{~m}$ thick and consists of centimeter-scale low- to high-angle $\left(19^{\circ}-5^{\circ}\right)$ cross stratification dipping to the southeast $\left(\sim 135^{\circ}\right)$. The Smith and Steno units correlate with the diagenetic banding observed at other promontories, most notably Cape St. Vincent. At Cape St. Vincent the upper $0.6 \mathrm{~m}$ of fractured in place bedding in similar to Steno, while the remaining $0.8 \mathrm{~m}$ of the bright band are texturally similar to Smith, suggesting that the erosional contact between Smith and Steno is unrelated to the digenetic event(s) that produce the bright banding. Similar comparisons can be made at Cabo Corrientes and Cape Desire.

[25] The Smith-Steno contact in the Reference Section is $25 \mathrm{~m}$ north and $20 \mathrm{~m}$ east of the Cape Verde bounding surface. The absolute vertical difference between the two locations is $\sim 2 \mathrm{~m}$. If a dip azimuth of east-southeast is assumed $\left(115^{\circ}\right)$ the expected vertical offset along the dip plane at Cape Verde would be $2.3 \mathrm{~m}$. Thus, the dip magnitude and orientation of the Smith-Steno contact approximately agree with the orientation of the bounding surface at Cape Verde. The stratification style of units above and below the bounding surfaces at Cape Verde and the

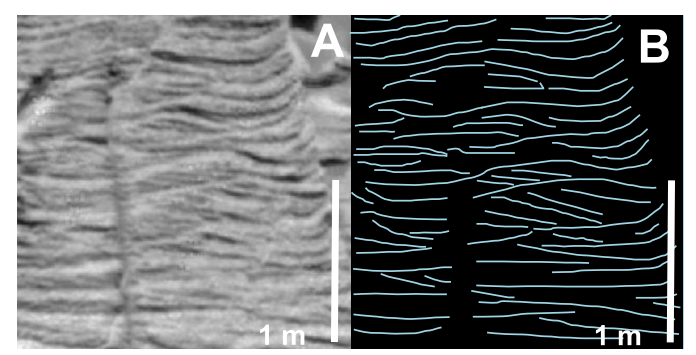

Figure 9. (a)Small decimeter-scale features exposed on the south face of Cape St. Mary. (b) The features are superimposed on primary bedding and high-angle foresets, likely formed by the complex wind patterns existing within the troughs of migrating bed forms. The image is cropped from the superresolution sequence P2441 obtained on sol 1212 (6 June 2007). The artifacts visible on the left side of the image are the result of saturated pixels in the superresolution processing. 


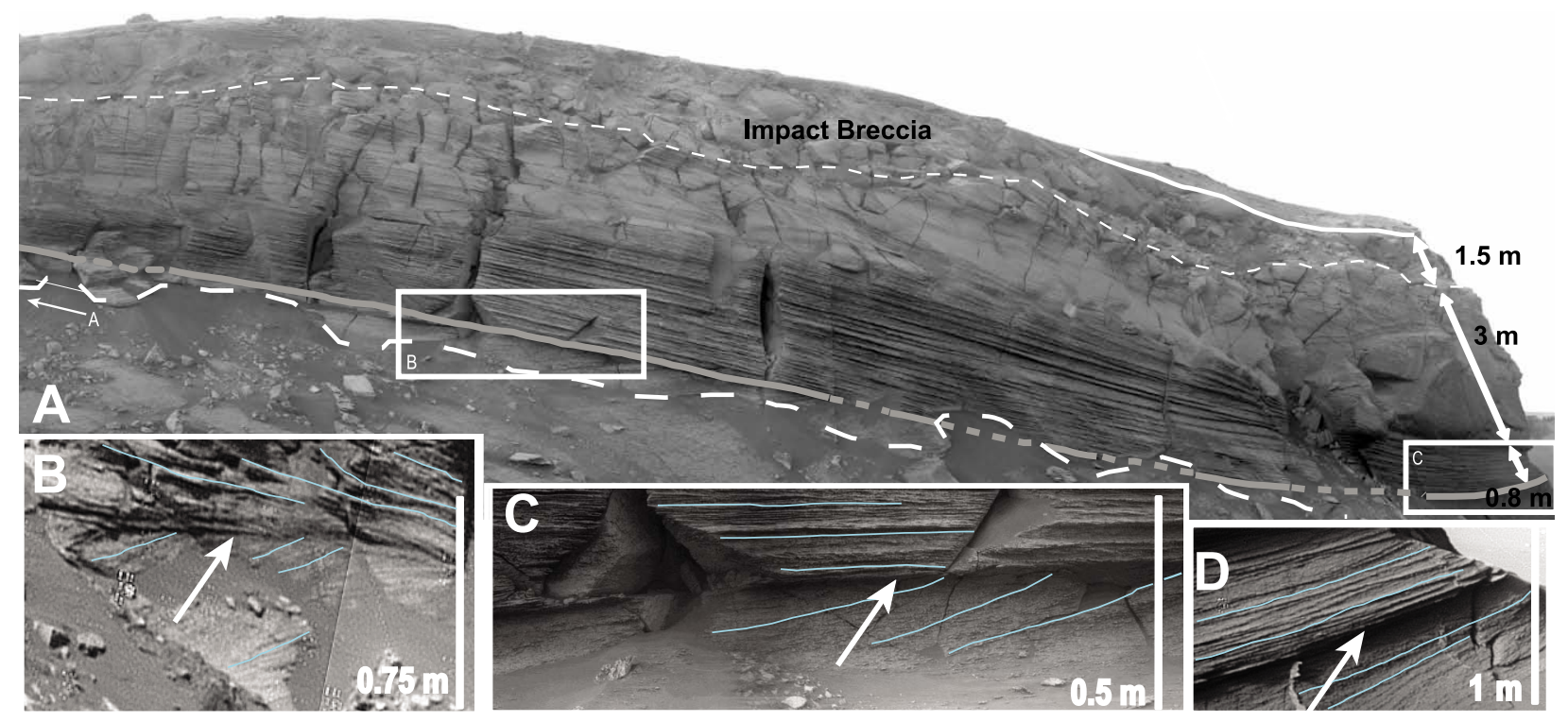

Figure 10. Image mosaic of the south face of Cape Verde generated from sequence P2396 on sols 15791580 (2-3 July 2008) using Pancam's 753 nm filter. Cape Verde exposes two primary units, divided by a bounding surface located at its base (below I). The surface truncates bedding, but overlying strata are concordant with its $10^{\circ}-13^{\circ}$ dip to the east-southeast. Bedding below the bounding surface dip toward the south with magnitudes between $10^{\circ}$ and $20^{\circ}$. The upper unit consists of low- to high-angle cross stratification with dips to the southeast. Dip magnitudes steepen upward in the outcrop, ranging from low angle $\left(6^{\circ}-15^{\circ}\right)$ near the truncation surface to high angle $\left(18^{\circ}-35^{\circ}\right)$ in the uppermost sections. Exposed strata are covered by $\sim 2 \mathrm{~m}$ of impact breccia, and a block slump event has deformed the preimpact surface. Superresolution frames taken between sols 1574 and 1578 showing the details of the bounding surface at the base of the outcrop. Diagenetic features, including truncated and crosscutting fracture fills (Figure 11c) and ribbed weathering superimposed on cross strata, are also visible in the outcrop.

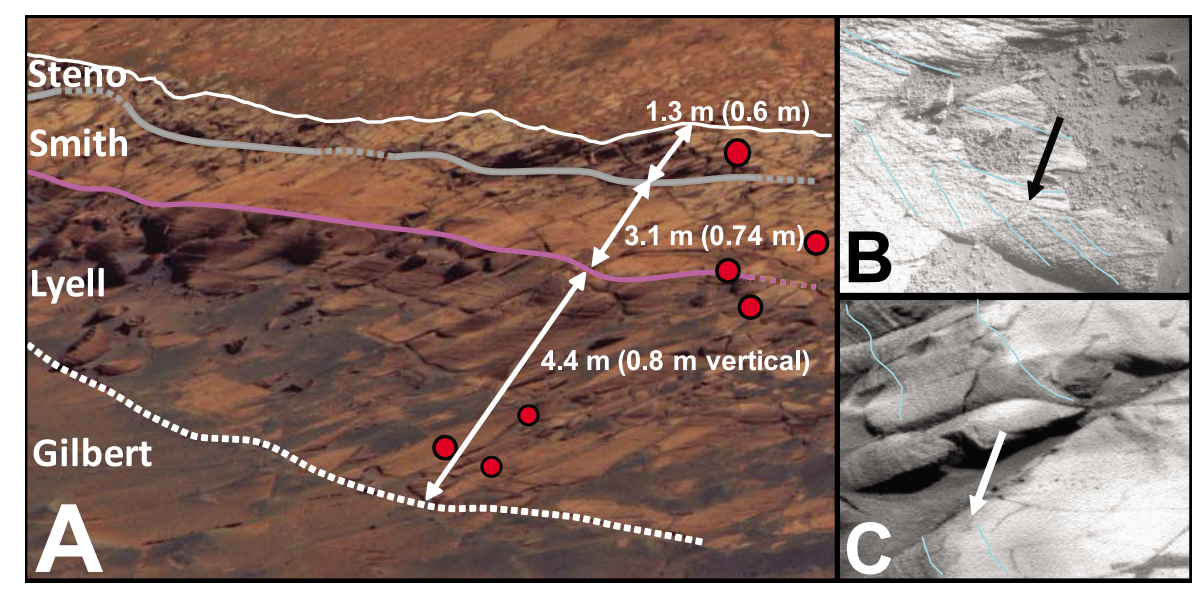

Figure 11. (a) Ingress section of Duck Bay, where Opportunity entered Victoria Crater in September 2007. Stratigraphic units are named Lyell, Smith, and Steno. Gilbert refers to the area below Lyell where stratigraphy is not exposed. The contact between Lyell and Smith is diagenetic, while the contact between Smith and Steno is erosional, with a dip of $10^{\circ}-13^{\circ}$ to the east-southeast. Lyell exposes low-angle meterscale cross bedding dipping to the south-southwest. Smith is approximately $1 \mathrm{~m}$ thick and appears massive but shows some evidence for stratification that can be traced across the Lyell-Smith contact. Steno is $\sim 0.6 \mathrm{~m}$ thick and consists of high-angle $\left(12^{\circ}-25^{\circ}\right)$ cross stratification dipping to the southeast. The Smith-Steno contact can be correlated to the bounding surface at the base of Cape Verde. (b and c) Examples of the Smith-Steno erosional contact (Figure 11b) and Lyell-Smith diagenetic contact (Figure 11c). Red dots correspond to locations brushed by the Rock Abrasion Tool and analyzed using the rover's in situ instrument package. 
Reference Section are also similar, suggesting that these surfaces can be correlated. The surface is not exposed on the north face of Cape Verde or at Cape St. Mary.

\section{Discussion}

\subsection{Accumulation of Ancient Eolian Deposits}

[26] The outcrops exposed along the promontories and embayments of Victoria Crater provide a data set of unprecedented resolution with which to interpret the processes that operated on the ancient surface of Mars. The lateral continuity shown in the correlation of general facies between promontories provides strong evidence for a widespread eolian dune complex, composed of sand-sized grains with mixed sulfate/altered silicate composition. In this regard, the rocks at Victoria are strikingly similar to those seen earlier on during Opportunity's mission, suggesting a dry landscape over a broad region of at least $6 \mathrm{~km}$ in lateral extent, that was only intermittently wet at the surface. At Victoria, evidence for only eolian sedimentation is recorded, at least in the quadrant of the crater that was studied by Opportunity.

[27] One feature that is notably absent from the bedrock outcrops at Victoria Crater is evidence for periods of even brief subaqueous deposition, as observed at Eagle, Endurance and Erebus craters [Grotzinger et al., 2005; Metz et al., 2009]. Metz et al. [2009] suggest that as the rover has moved stratigraphically higher through Eagle, Endurance and Erebus craters, such that it has observed a full climatic cycle, from dry to wet to dry conditions. The bedrock outcrops at Victoria Crater represent a stratigraphically higher section than that observed at Eagle and Endurance craters, and may represent even drier climatic conditions and increased sediment flux. Alternatively, the lack of evidence for aqueous deposition may indicate lateral variations in time-equivalent facies. Victoria Crater may expose strata from the center of a well-developed sand sea, whereas strata in Eagle and Endurance craters may represent depressions within the sand sea and be more prone to the emergence of groundwater. Assuming that the Meridiani strata are flat lying, we can use elevation and facies descriptions to produce a stratigraphic correlation between the different craters. The outcrop exposed in the Reference Section at Duck Bay lies at a similar elevation as the uppermost unit exposed in Erebus crater. The upper unit of the Yavapai formation is interpreted to represent sandsheet/dune field facies [Metz et al., 2009]. It is possible that the upper unit at Erebus represents the same period of deposition observed in the ingress path at Duck Bay, but the larger scale of the outcrops at Victoria Crater exposes the stratal geometries consistent with construction of larger-scale eolian bed forms.

[28] The eolian strata expressed in the Victoria outcrops also suggest that the ancient dune field has several scales of superimposed bed forms. The evidence for this is not provided by the rocks themselves, but rather by the distribution of bounding surfaces that delineate rock units. Studying the hierarchical structure of bounding surfaces, their specific geometries, and dip directions, can provide a detailed understanding of bed form dynamics [Kocurek, 1991; Rubin, 1983; Ahlbrandt and Fryberger, 1981]. With this in mind, we now discuss the significance of the surfaces that bound sets of cross stratification in the Burns Formation at Victoria Crater.

[29] Bounding surfaces are prominent in nearly all eolian units, and can be produced in a variety of ways. The recognition of bounding surfaces in ancient eolian deposits is helpful in reconstructing paleoflow direction, the nature of dune migration, and ultimately the sequence of events that produced the deposit [Brookfield, 1977]. In turn, this may enable some understanding of changes in climate, sand supply, and possible subsidence. The largest-scale bounding surfaces that are seen at Victoria, such as those which extend from Duck Bay to Cape Verde or Cape Desire to Cabo Corrientes, may represent the migration of dunes on a larger bed form [Fryberger, 1993]. The larger bed form underlying the bounding surface may betermed a draa. Wilson [1972] first used the term draa to refer to a distinctly larger bed form with wavelengths of $0.5-5 \mathrm{~km}$. As it has been shown that there is not a distinct size break between draa and dune [Wasson and Hyde, 1983], Kocurek [1981] used the term draa to refer to dunes with superimposed dunes, to distinguish them from simple dunes. Dunes with superimposed dunes can be classified as compound, which consists of the same kind of dunes, or complex, which are made up of different kinds of dunes. The terminology proposed by Kocurek [1981] is useful when interpreting ancient deposits because it is typically difficult to determine compound from complex dunes in the rock record. Based on the stratal geometries that suggest migrating dunes in close proximity to bounding surfaces at Victoria Crater, it is reasonable to assume that dunes migrating across a larger bed form may have produced the large-scale nonplanar erosional surfaces observed at Duck Bay, Cape Verde, Cape Desire, and Cabo Corrientes.

[30] The stratal geometries and cross-bed dip directions recorded at Victoria also provide evidence for multiple wind directions, including reversal of flow. These opposing foreset dip azimuths observed across the bounding surfaces at Cabo Corrientes and Cape Desire may represent set boundaries between two dunes migrating in opposing directions. These surfaces, recognized as discontinuities in the lateral sequence of cross strata, require reconstitution and reversal of the migrating bed form and indicate a change in wind direction or velocity. This interpretation is consistent with observations of terrestrial draas, which may contain such reactivation surfaces representing the migration of smaller-scale dunes across a draa in opposite directions [McKee, 1966]. A likely interpretation of this result is longperiod oscillations of wind direction driving dunes back and forth across an ancient draa.

\subsection{Alternative Depositional Scenarios}

[31] At least two alternative depositional models have been suggested for cross-stratified deposits seen in Meridiani Planum. McCollom and Hynek [2005] suggest that Meridiani strata may represent a volcanic base surge deposit, and Knauth et al. [2005] suggest that Meridiani strata may have formed by an impact-induced base surge. However, these alternative interpretations are inconsistent with the regional geological context and there is no evidence for contemporaneous sources of volcanism or impacts of sufficient size to produce base surge deposits as thick as the stratigraphic succession observed at Meridiani [Squyres et al., 2006; 


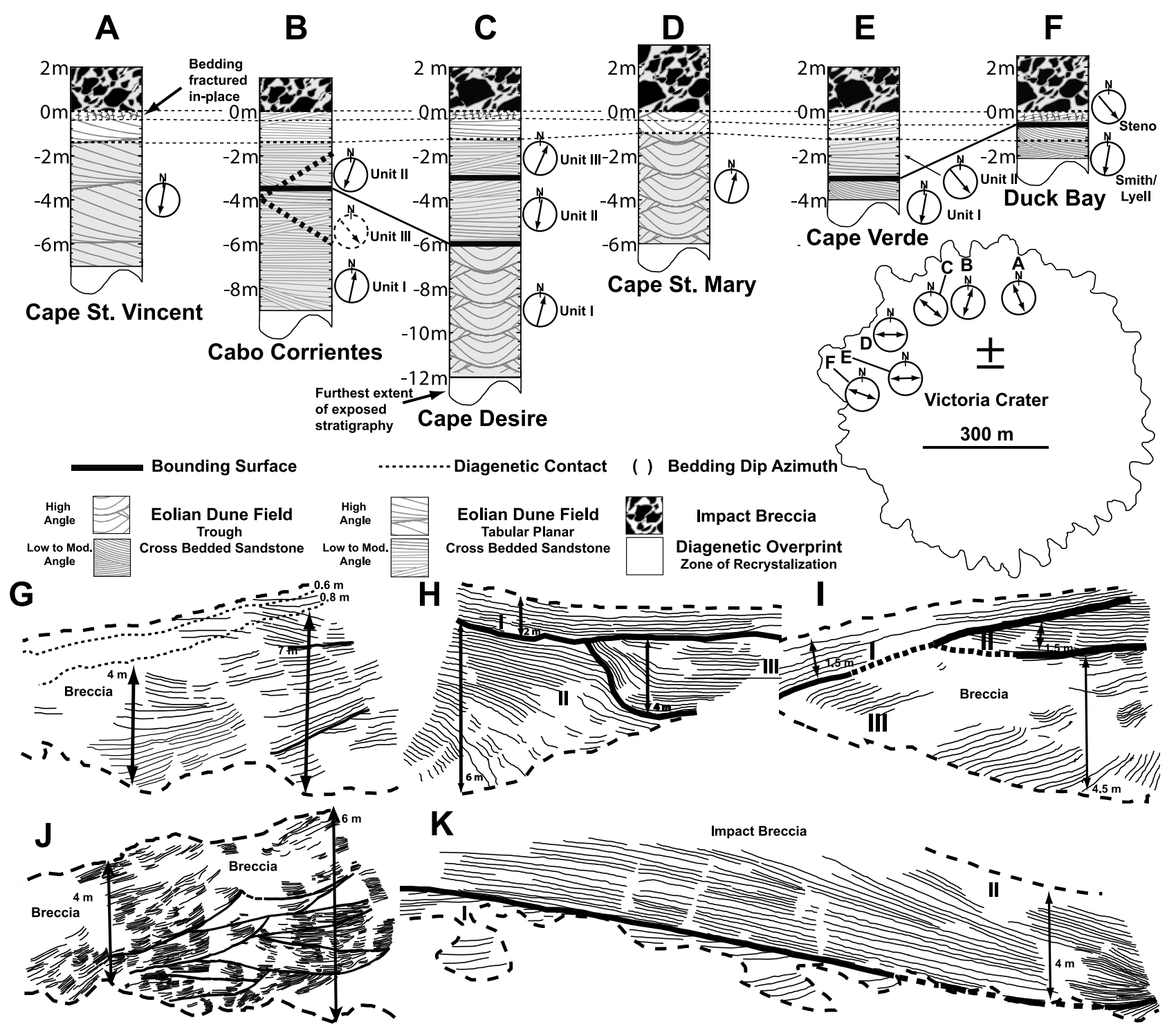

Figure 12. (a-f) Stratigraphic columns and $(\mathrm{g}-\mathrm{k})$ layer tracings for investigated promontories at Victoria Crater. Bedding is referenced to the preimpact surface and made up of eolian dune deposits with superimposed bands of diagenetic recrystallization. The preimpact surface vertically varies by $\sim 7$ between Duck Bay and Cape St. Vincent (Figure 1c). Bedding orientations above and below bounding surfaces suggest oscillatory paleocurrent directions. Lines of correlation between columns indicate possible interpromontory continuity between erosional and diagenetic surfaces. Predominant dip azimuths are listed next to each column and outcrop trends are depicted within the rim tracing of Victoria Crater. Note that stratigraphic columns display average unit thickness, while actual thicknesses can spatially vary within each outcrop. Also note that unit III of Cabo Corrientes (Figure 6) pinches out laterally within the outcrop and is only exposed on one face. Outcrop tracings in Figures $12 \mathrm{~g}-12 \mathrm{k}$ correspond to stratigraphic columns in Figures 12a-12e.

McLennan and Grotzinger, 2008]. Additionally, if the abundant spherules found in many Meridiani outcrops are iron condensation spherules or accretionary lapilli as proposed by Knauth et al. [2005], rather than diagenetic concretions, they should show concentrations along bedding planes that represent scour surfaces [Fralick, 2011]. McLennan et al. [2005] show that spherules observed in Eagle and Endurance craters are highly dispersed relative to bedding, and the same relationship is observed in Victoria Crater. In particular, Edgar et al. [2011] show that the spherules observed in the ingress path at Duck Bay are dispersed across all strata and are not concentrated at the erosional surface between Smith and Steno, nor any of the other cross-bed set boundaries, suggesting that the spherules formed in situ after deposition of the sediments. Furthermore, the scale of cross bedding observed at Victoria provides a compelling case for an eolian depositional environment, as cross bedding of this large magnitude requires bed forms on the order of tens of meters [Ahlbrandt and Fryberger, 1981], a scale which is at least an order of 


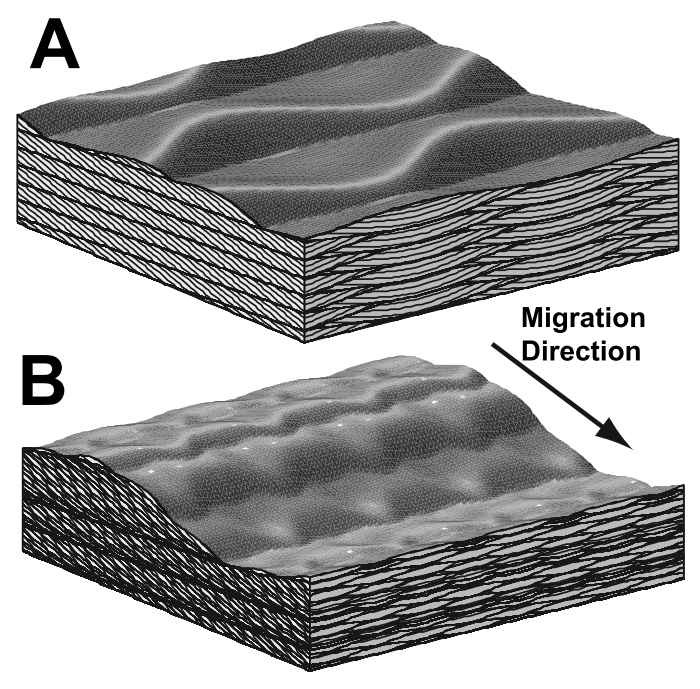

Figure 13. Three-dimensional bed form structures created using the techniques outlined in Appendix 2 of Rubin and Carter [2006]. (a) Cross-bedding deposits formed from three-dimensional bed forms with curved, out-of-phase crest lines and a sine-shaped planform. Trough-shaped set of cross bedding, similar to those observed at Cape St. Mary, is observed on faces perpendicular to the migration direction. Along the migration direction, tabular planar sets of strata are deposited, similar to bedding observed at Cape St. Vincent. (b) Structure formed by two-dimensional bed forms with downslope migrating superimposed threedimensional bed forms similar to those described in Figure 13a. This scenario is an example of the bed form geometry proposed for Victoria Crater, with the large-scale erosional surfaces representing the migration direction of the larger bed form.

magnitude larger than any known base surge deposits. Finally, in 6 years of surface operations not one feature has been observed in the Burns Formation that could be interpreted as a volcanic bomb, or impact ejecta.

[32] The paleocurrent study here adds significant new support to the eolian interpretation. The observation of superimposed strata with cross-bedding geometries that require reversal of flow direction is problematic for the base surge mechanism. In the volcanic interpretation it would require separate sources on opposite sides of Meridini Planum. In the case of the impact surge mechanism it would also require impacts at opposite sides of Meridiani. In both cases this requires an unlikely scenario for which there is little evidence, especially in the case of the volcanic hypothesis. In the case of the impact surge hypothesis, our data directly contradict the model proposed by Knauth et al. [2005]: that a single large impact, represented by Schiaparelli crater, produced the deposit represented by the Burns Formation. And while multiple large impacts on the surface of Mars at the time of deposition of the Burns would not be unreasonable, we would predict a more random distribution. Furthermore, the sedimentologic observations strongly rule against this possibility as discussed previously in this paper, and in others before it [Grotzinger et al., 2005, 2006; McLennan and Grotzinger, 2008; Metz et al., 2009].
[33] A final point, regarding the sedimentology of these cross-bedded deposits, is the absence of stratification on the stoss sides of the paleobed forms. All cross bedding represents only a small fraction of the height of the original bed forms, specifically the toes of the lee sides of those bed forms. Base surge deposits commonly are associated with high settling rates of suspended materials [Branney and Kokelaar, 1992], and therefore may show high angles of climb with preservation of sediment along the stoss (up current) side of the bed form. This has not been observed at any outcrop visited by Opportunity, and the exposures at Victoria Crater make a firm point of this.

\subsection{Stratal Architecture and Reconstruction of Eolian Environments}

[34] The orientation and classification of cross-bedded sets, bounding surfaces, and stratification types described in section 4 suggest that Victoria Crater sits within an ancient eolian dune field with predominantly north-south and southnorth paleowind directions (Figure 12). The bounding surface observed between Cape Verde and the ingress section also suggests an eastward migrating larger-scale bed form. The outcrops at the Cape St. Mary and Cape St. Vincent promontories, which are located at opposite ends of the rim traverse, have proven to be the best examples of meter-scale cross bedding observed on Mars to date. Furthermore, Cape St. Mary (Figure 8) is the only promontory whose outcrop clearly shows multiple sets of cross strata. While Cape St. Vincent also shows evidence for the presence of set boundaries, they are not as obvious and significantly fewer sets are preserved in the outcrop.

[35] The cross bedding at Cape St. Mary consists of meter-scale trough-shaped sets of stratification that are indicative of bed forms with closed depressions, or scour pits (Figure 13a). The uniform distribution and truncation of troughs by younger troughs within bed sets at Cape St. Mary can only be formed by transverse bed forms with curved, out-of-phase crest lines [Rubin, 1987]. The symmetrical shapes of the troughs themselves suggest that the paleocurrent direction was nearly perpendicular to the outcrop face [DeCelles et al., 1983]. The bimodel distribution of dip azimuths with a mean north-northeast direction is consistent with the paleoflow running into the outcrop face.

[36] Cape St. Vincent, whose west face trends $110^{\circ}$ away from Cape St. Mary, shows meter-scale sets of parallel bedding that asymptotically lap down toward lower set boundaries. Foresets steepen upward, from near horizontal to high angle $\left(>15^{\circ}\right)$ at the top of the outcrop. This geometry is consistent with bed form migration along the face of the outcrop, from north-to-south (Figure 13a). The dip azimuths, while by themselves not an accurate estimate of migration direction due to the limited number of observable bed sets, support this hypothesis. Therefore, the stratification at Cape St. Vincent suggests a north-to-south paleoflow direction while the stratification at Cape St. Mary suggests at south-to-north paleoflow direction. The top of the Cape St. Mary section lies $5 \mathrm{~m}$ above the of the Cape St. Vincent outcrop, suggesting a reversal in transport direction if elevation is used as a proxy for stratigraphic position. While the Cape St. Mary and Cape St. Vincent outcrops cannot be directly correlated due to spatial gaps in the available data, promontories located between them contain directly super- 


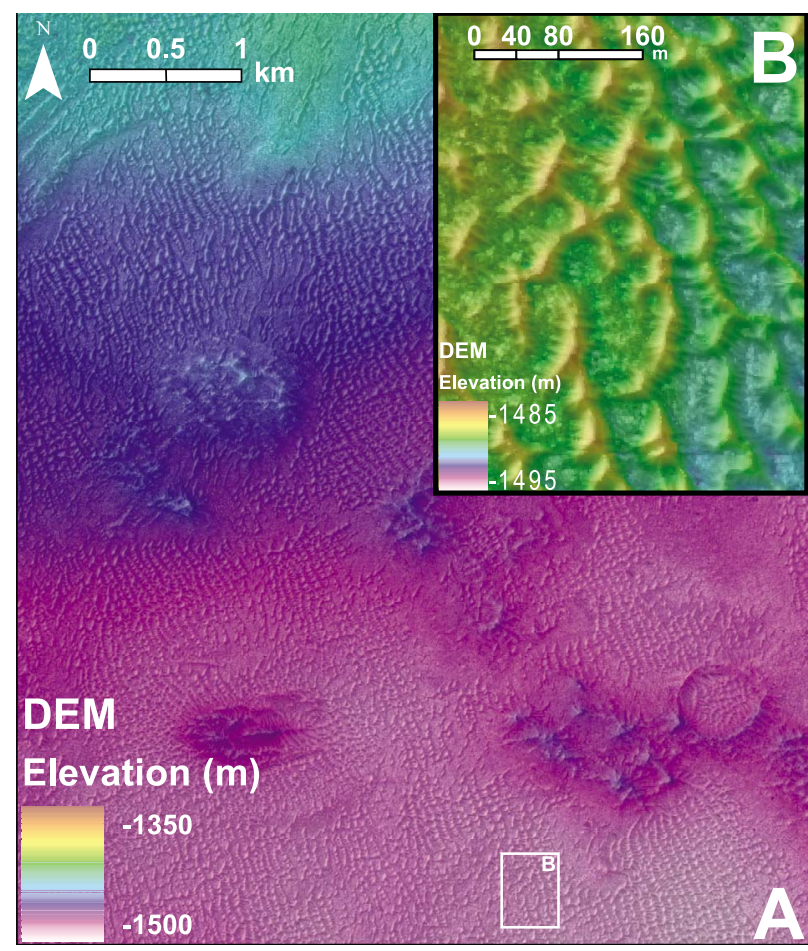

Figure 14. Equidistant cylindrical projection of eastern Nilli Fossae centered at $\left(78.993^{\circ} \mathrm{E}, 21.933^{\circ} \mathrm{N}\right)$. (a) Digital elevation model (DEM) created using subframes of HiRISE images PSP_001351_2020 and PSP_010074_2020. The area is dominated by complex dunes with a spacing of 50-70 m and heights of $\sim 3 \mathrm{~m}$. (b) Close-up of area outlined by white box in Figure 14a. Small-scale ripples can clearly be seen riding on the backs of larger-scale structures. This area represents a small-scale modern example of the paleobed form geometry proposed for Victoria Crater.

posed stratigraphic units with northward and southward foreset dips, separated by bounding surfaces which also have local northward or southward dips. These bedding orientations provide direct evidence for reversal of paleoflow direction. There are no higher-order bounding surfaces visible at Cape St. Mary or Cape St. Vincent.

[37] The stratigraphy and eolian architecture exposed at Cabo Corrientes, Cape Desire, Cape Verde, and Duck Bay provide strong evidence for reversing wind conditions, recorded by smaller dunes represented by meter-scale cross stratification. The larger-scale bounding surfaces exposed at these outcrops may represent the lee sides of draa, with superimposed dunes migrating along slope (Figure 13b). At Duck Bay and Cape Verde, the bounding surface dips $\sim 10^{\circ}$ to the east-southeast, while the more gently dipping ( $\leq 10^{\circ}$ to planar) bounding surfaces found at other promontories have northward and southward dips. Given the geometric relationship of the strata above and below the erosional surface, these surfaces may represent set boundaries between deposits from dunes migrating in opposing directions while riding on the back of a larger bed form. In this scenario, the orientation of the bounding surface (rather than the cross strata above the surface) may serve as a better indicator of the resultant wind direction at the time that the surface was formed.
[38] Finally, there are modern examples of this bed form geometry found on Mars today. Two such examples include a regional dune field in the eastern half of Nilli Fossae (Figure 14) and the star dunes in the center of Victoria Crater (Figure 1b). In both of these examples, we find smaller superimposed dunes riding on the backs of the larger dunes. Using DEMs created from HiRISE image pairs, we obtain estimates of the dune crest heights in both locations ranging from 2 to $5 \mathrm{~m}$. While these are smaller than the estimated heights of the ancient dunes preserved in the Victoria bedrock, these modern examples suggest that processes which govern ancient deposition are still acting on the modern Martian surface. In the case of the star dunes in Victoria, this analog is only partial in that the dunes clearly accumulate in response to a complex wind field in the center of the crater; for Meridiani at the time of Burns accumulation it would have been a vast and featureless plain, probably much as it is today. The complex eolian bed forms would have been produced by more regional wind patterns. The Nilli Fossae example, while closer to the expected environment in ancient Meridiani, is still only partial in that there is no evidence for reversing flows, the scale between primary and secondary bed forms is smaller than then that inferred by the Victoria bedrock, and there are no examples of nearby wet interdune environments.

\section{Summary}

[39] Outcrop exposures within the craters of Meridian Planum represent the most scrutinized sedimentary rocks on Mars, underpinning the development of a facies model that describes the history of the regional geology. The facies observed at Victoria Crater represent superb examples of meter-scale cross stratification. Cape St. Vincent and Cape St. Mary are comparable to Jurassic age eolian deposits of the western United States [Porter, 1986]. Bedding at Cape St. Vincent is indicative of a single climbing bed form migrating north to south with dune heights of several meters. Cape St. Mary is characterized by meter-scale trough cross bedding, suggesting sinuous crested dunes with scour pits migrating toward the north. While Cape St. Vincent and Cape St. Mary cannot be directly correlated due to spatial gaps in available data, promontories located between them contain directly superposed stratigraphic units with northward and southward dipping foresets separated by outcrop-scale bounding surfaces. These bedding orientations provide direct evidence for reversal of paleoflow and, as a consequence, force any depositional model proposed for the cross-stratified facies observed at Victoria Crater to accommodate these reversals.

[40] Sedimentary rocks provide clues regarding the nature of their depositional environment, and can be used to provide insight into past climatic regimes and potential habitability [Grotzinger et al., 2005; Squyres et al., 2004a]. With the addition of the stratigraphy present at Victoria Crater the dune-interdune deposition model for the Burns Formation, originally described by Grotzinger et al. [2005], can be extended vertically by $\sim 7 \mathrm{~m}$ and laterally by up to $3 \mathrm{~km}$. Reversing paleoflow directions, large-scale bed sets, absence of ballistic detritus, and lack of stoss-side preservation suggest that volcanic and impact-induced surge deposits are unlikely to have formed the Burns Formation. 
Instead, we propose that the Burns Formation represents an ancient dune field with several scales of superimposed bed forms. Extended bounding surfaces observed at Cabo Corrientes, Cape Desire, Cape Verde, and Duck Bay may represent draa-scale reactivation surfaces which are responding to shifting wind conditions. While the stratigraphy present at Victoria Crater is consistent with the eolian interpretation of the dune-interdune model, no evidence for subaqueous deposition was observed. As such, the bedrock outcrops at Victoria could represent drier climatic conditions as compared to the depositional environment in place when the bedrock exposed by Endurance Crater was deposited. Alternatively, the lack of subaqueous deposition may indicate lateral variations intime-equivalent facies.

[41] Acknowledgments. The authors would like to thank Kevin Lewis, Joannah Metz, and David Rubin for helpful discussions; Ryan Ewing for a detailed review which substantially improved the manuscript; and the MER engineering team, without whom the data presented here would not have been possible.

\section{References}

Ahlbrandt, T. S., and S. G. Fryberger (1981), Introduction to eolian deposits, Am. Assoc. Pet. Geol. Bull., 31, 11-47.

Arvidson, R. E., F. P. Seelos IV, K. S. Deal, W. C. Koeppen, N. O. Snider J. M. Kieniewicz, B. M. Hynek, M. T. Mellon, and J. B. Garvin (2003), Mantled and exhumed terrains in Terra Meridiani, Mars, J. Geophys. Res., 108(E12), 8073, doi:10.1029/2002JE001982.

Bell, J. F., et al. (2003), Mars Exploration Rover Athena Panoramic Camera (Pancam) investigation, J. Geophys. Res., 108(E12), 8063, doi:10.1029/2003JE002070.

Bell, J. F., III, J. Joseph, J. N. Sohl-Dickstein, H. M. Arneson, M. J. Johnson, M. T. Lemmon, and D. Savransky (2006), In-flight calibration and performance of the Mars Exploration Rover Panoramic Camera (Pancam) instruments, J. Geophys. Res., 111, E02S03, doi:10.1029/ 2005JE002444.

Branney, M. J., and P. Kokelaar (1992), A reappraisal of ignimbrite emplacement: Progressive aggradation and changes from particulate to nonparticulate flow during emplacement of highgrade ignimbrite, Bull. Volcanol., 54, 504-520, doi:10.1007/BF00301396.

Brookfield, M. E. (1977), The origin of bounding surfaces in ancient aeolian sandstones, Sedimentology, 24, 303-332, doi:10.1111/j.13653091.1977.tb00126.x.

Christensen, P. R., et al. (2000), Detection of crystalline hematite mineralization on Mars by the Thermal Emission Spectrometer: Evidence for near-surface water, J. Geophys. Res., 105, 9623-9642, doi:10.1029/ 1999JE001093.

Christensen, P. R., et al. (2004), Mineralogy at Meridiani Planum from the Mini-TES Experiment on the Opportunity Rover, Science, 306(5702), 1733-1739, doi:10.1126/science.1104909.

DeCelles, P. G., R. P. Langford, and R. K. Schwartz (1983), Two new methods of paleocurrent determination from trough cross-stratification, J. Sediment. Res., 53(2), 629-642.

Di, K., F. Xu, J. Wang, S. Agarwal, E. Brodyagina, R. Li, and L. Matthies (2008), Photogrammetric processing of rover imagery of the 2003 Mars Exploration Rover mission, J. Photogramm. Remote Sens., 63(2), 181201, doi:10.1016/j.isprsjprs.2007.07.007.

Dunteman, G. H. (1989), Principal Component Analysis, Sage, Thousand Oaks, Calif.

Edgar, L. A., J.P. Grotzinger, A. H. Hayes, D. M. Rubin, S. W. Squyres, J. F. Bell, and K. E. Herkenhoff (2011), Stratigraphic architecture of bedrock reference section, Victoria Crater, Meridiani Planum, Mars, in Sedimentary Geology of Mars, edited by J. Grotzinger and R. Milliken, Spec. Publ. Soc. Sediment. Geol., in press.

Edgett, K. S. (2005), The sedimentary rocks of Sinus Meridiani: Five key observations from data acquired by the Mars Global Surveyor and Mars Odyssey orbiters, Mars, 1, 5-58, doi:10.1555/mars.2005.0002.

Edgett, K. S., and T. J. Parker (1997), Water on early Mars: Possible subaqueous sedimentary deposits covering ancient cratered terrain in western Arabia and Sinus Meridiani, Geophys. Res. Lett., 24, 2897-2900, doi:10.1029/97GL02840.

Ewing, R. C., A.-P. B. Peyret, G. Kocurek, and M. Bourke (2010), Dune field pattern formation and recent transporting winds in the Olympia
Undae Dune Field, north polar region of Mars, J. Geophys. Res., 115, E08005, doi:10.1029/2009JE003526.

Fralick, P. W. (2011), Characteristics of the ejecta layer from the $1.85 \mathrm{Ga}$ Sudbury impact event: Are analogous sediments present on Mars? in Sedimentary Geology of Mars, edited by J. Grotzinger and R. Milliken, Spec. Publ. Soc. Sediment. Geol., in press.

Fryberger, S. G. (1993), A review of aeolian bounding surfaces, with examples from the Permian Minnelusa Formation, USA, GEOL. SOC. SPEC. PUBL., 73(1), 167-197, doi:10.1144/GSL.SP.1993.073.01.11.

Golombek, M. P., et al. (2003), Selection of the Mars Exploration Rover landing sites, J. Geophys. Res., 108(E12), 8072, doi:10.1029/ 2003JE002074.

Grant, J. A., S. A. Wilson, B. A. Cohen, M. P. Golombek, P. E. Geissler, R. J. Sullivan, R. L. Kirk, and T. J. Parker (2008), Degradation of Victoria Crater, Mars, J. Geophys. Res., 113, E11010, doi:10.1029/ 2008JE003155.

Grotzinger, J. P., et al. (2005), Stratigraphy and sedimentology of a dry to wet eolian depositional system, Burns formation, Meridiani Planum, Mars, Earth Planet. Sci. Lett., 240, 11-72, doi:10.1016/j. eps1.2005.09.039.

Grotzinger, J., et al. (2006), Sedimentary textures formed by aqueous processes, Erebus crater, Meridiani Planum, Mars, Geology, 34, 1085-1088, doi:10.1130/G22985A.1

Knauth, L. P., D. M. Burt, and K. H. Wohletz (2005), Impact origin of sediments at the Opportunity landing site on Mars, Nature, 438, 1123 1128, doi: 10.1038 /nature 04383 .

Kocurek, G. (1981), Distinctions and uses of stratification types in the interpretation of eolian sand, J. Sediment. Res., 51, 579-595.

Kocurek, G. (1991), Interpretation of ancient eolian sand dunes, Annu. Rev. Earth Planet. Sci., 19, 43-75, doi:10.1146/annurev.ea.19.050191.000355.

McCollom, T. M., and B. M. Hynek (2005), A volcanic environment for bedrock diagenesis at Meridiani Planum on Mars, Nature, 438, 11291131, doi:10.1038/nature04390

McKee, E. D. (1966), Structures of dunes at White Sands National Monument, New Mexico (and a comparison with structures of dunes from other selected areas), Sedimentology, 7, 3-69, doi:10.1111/j.13653091.1966.tb01579.x.

McLennan, S. M., and J. P. Grotzinger (2008), The sedimentary rock cycle of Mars, in The Martian Surface-Composition, Mineralogy, and Physical Properties, edited by J. Bell III, pp. 541-577, Cambridge Univ. Press, Cambridge, U. K., doi:10.1017/CBO9780511536076.025.

McLennan, S. M., et al. (2005), Provenance and diagenesis of the evaporite-bearing Burns formation, Meridiani Planum, Mars, Earth Planet. Sci. Lett., 240, 95-121, doi:10.1016/j.epsl.2005.09.041.

Metz, J. M., J. P. Grotzinger, D. M. Rubin, K. W. Lewis, S. W. Squyres, and J. F. Bell (2009), Sulfate-Rich Eolian and Wet Interdune Deposits, Erebus Crater, Meridiani Planum, Mars, J. Sediment. Res., 79, 247 264, doi:10.2110/jsr.2009.033.

Porter, M. L. (1986), Sedimentary record of erg migration, Geology, 14(6), 497-500, doi:10.1130/0091-7613(1986)14<497:SROEM>2.0.CO;2.

Presley, M. A., R. E. Arvidson, and P. R. Christensen (1987), Characterization of surficial units on Mars using Viking orbiter multispectral image and thermal data, in Reports of Planetary Geology and Geophysics Program, pp. 178-180, NASA, Washington, D. C.

Rubin, D. M. (1983), Reconstructing bedform assemblages from compound crossbedding, in Eolian Sediments and Processes, edited by M. E. Brookfield and T. S. Ahlbrandt, pp. 407-427, Elsevier Sci., New York, doi:10.1016/S0070-4571(08)70807-0

Rubin, D. M. (Ed.) (1987), Cross-Bedding, Bedforms, and Paleocurrents, Concepts Sedimentol. Paleontol., vol. 1, Soc. of Econ. Paleontol. and Mineral, Tulsa, Okla., doi:10.2110/csp.87.01.

Rubin, D. M., and C. L. Carter (2006), Bedforms and cross-bedding in animation, SEPM Atlas Ser. 2, Soc. for Sedment. Geol., Tulsa, Okla.

Squyres, S. W., et al. (2004a), The Opportunity Rover's Athena science investigation at Meridiani Planum, Mars, Science, 306, 1698-1703, doi:10.1126/science.1106171.

Squyres, S. W., et al. (2004b), In situ evidence for an ancient aqueous environment at Meridiani Planum, Mars, Science, 306, 1709-1714, doi:10.1126/science.1104559.

Squyres, S. W., et al. (2006), Planetary science: Bedrock formation at Meridiani Planum, Nature, 443, E1-E2, doi:10.1038/nature05212.

Squyres, S. W., et al. (2009), Exploration of Victoria Crater by the Mars Rover Opportunity, Science, 324(5930), 1058-1061, doi:10.1126/science. 1170355.

Wasson, R. J., and R. Hyde (1983), Factors determining desert dune type, Nature, 304, 337-339, doi:10.1038/304337a0.

Watters, W. A., J. P. Grotzinger, J. Bell III, J. Grant, A. G. Hayes, R. Li, S. W. Squyres, and M. T. Zuber (2011), Origin of the structure and planform of small impact craters in fractured targets: Endurance crater 
at Meridiani Planum, Mars, Icarus, 211(1), 472-497, doi:10.1016/j. icarus.2010.08.030

Wilson, I. G. (1972), Universal discontinuities in bedforms produced by the wind, J. Sediment. Res., 42, 667-669.

L. A. Edgar and J. P. Grotzinger, Division of Geological and Planetary Sciences, MC 170-25, California Institute of Technology, Pasadena, CA 91125, USA.
A. G. Hayes, Division of Geological and Planetary Sciences, MC 150-21, California Institute of Technology, Pasadena, CA 91125, USA. (hayes@ gps.caltech.edu)

J. Sohl-Dickstein, Biophysics Group, MC3200, University of California, Berkeley, CA 14853, USA.

S. W. Squyres, Astronomy Department, Cornell University, 428 Space Sciences Building, Ithaca, NY 14853, USA.

W. A. Watters, Astronomy Department, Cornell University, 426 Space Sciences Building, Ithaca, NY 14853, USA. 